\title{
Impacts of Anthropogenic Factors on Urban Air Quality in Lagos Metropolis
}

\author{
Peter Nkashi AGAN ${ }^{1}$ \\ ${ }^{1}$ Department of Geography, Faculty of Science, University of Ibadan, Ibadan, Oyo state, Nigeria \\ Correspondence: Peter Nkashi AGAN, Department of Geography, Faculty of Science, University of Ibadan, Ibadan, \\ Oyo state, Nigeria. Tel: 234-816-620-7854. E-mail: aganpee@gmail.com/aganism56@yahoo.com
}

Received: January 3, 2019

Accepted: January 10, 2019

Online Published: February 25, 2019

doi:10.5539/jgg.v11n2p35

URL: http://dx.doi.org/10.5539/jgg.v11n2p35

\begin{abstract}
Land use is the utilization and reordering of land cover for human comfort. This process disrupts the pristine state of the environment reducing the quality of environmental receptors like water, air, vegetation etc. Air pollution is introduced into the environment as a result of anthropogenic activities from commercial, industrial and residential areas. These activities are burning of fossil fuels for power generation, transport of goods and services, valorization of raw materials into finished products, bush burning, use of gas cookers, generators and electric stove etc. The introduction of pollutants into the planetary layer of the atmosphere has impacted negatively on the quality of the environment posing threat to humans and the survival of the ecosystem.

In Lagos metropolis, commercial activities and high population densities have caused elevated levels of pollution in the city. This study aimed to investigate the spatial distribution of pollutant in Lagos metropolis with a view to revealing the marked spatial/temporal difference in pollutants levels over residential, commercial and industrial land uses. Commercial and industrial land uses revealed higher levels of pollutants than the residential areas. Pearson product moment correlation coefficients revealed strong positive relationship between land use and air quality in the city.
\end{abstract}

Keywords: anthropogenic factors, air quality, pollutants, land uses, urban area etc

\section{Introduction}

Land use is the continuous ordering of anthropogenic activities and other physical structures within a geographical area (Gang et al 2016). Land use was first coined by Stamp in 1948 and defined as the utilization of land cover by man for economic, cultural, social and political functions which reflects the physical use of land for a new activity or an existing utilization of land for the enjoyments and comfort of man (Bicik et al 2015).Several definitions of land use have been put forward; according to Bicik et al (2015) the Food and Agricultural Organization(FAO) in 1998 referred to land use as the arrangements of activities and human inputs on a land cover for its production, transformation and maintenance. Consistent with this is Lambin et als (2006) definition of land use as the exploitation of land cover by humans which include the attributes biophysical manipulation of lands and the intentions attached to it in order to reflects the states of the landscape by the attitudes of both users and owners of lands (Bicik et al 2015). This manipulations of land cover has geometrically increased over the centuries through increasing anthropogenic activities creating phenomenal changes on the land cover and stress on the environmental coping capacity (Gang et al 2016).

Air pollution is the contamination of the atmosphere with undesirable solids, liquids and gases in concentrations that are likely to be harmful to humans and the environment. Air Pollution is bifurcated into gaseous and particulate pollutants where gaseous pollutants are carbon (iv) oxide (CO2), carbon (ii) oxide (CO), hydrocarbons, sulphur compounds and nitrogen compounds etc. and particulate pollutants are solids and liquids particles varying from

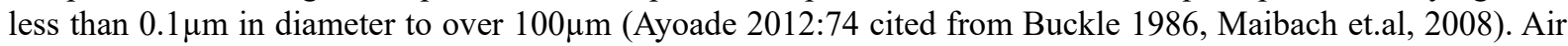
pollution is one of the many environmental problems currently affecting cities globally as they expand in population, size and economic activities. These economic activities which stemmed from rapid urbanization and high population densities have resulted in increased energy consumption, vehicular traffic and industrial emissions within the city built-up areas. These have exacerbated air pollution, urban heat island effects and ozone production within the city center (due to increase in impervious surfaces) to the surrounding country sides (Gang et al 2016, Superczynski and Sundar 2011 and Wang, et al 2017). 
According to Roychowdhury, et al (2016) Nigerian cities are phenomenally motorized with over 6million registered vehicles and an average increase of 400,000 vehicles annually accounting for one third of Nigerians middle class with less than two cars of five years old. This situation is the major cause of air pollution in cities especially Lagos and Abuja due to incomplete combustions contributing high emissions of carbon compounds containing nitrogen e.g. per acetyl nitrides, carbon monoxide, 3:4 benzopyrene, NOx, SOx, chlorinated organic compounds, ozonides aldehydes, peroxides and ketones. Prior to this, the Guardian Newspaper of Saturday 31st October 2015 report on the impacts of land use on air pollution stated that; the combustion of fossil fuels for power generation, transport and other anthropogenic activities results in a complex mixture of pollutants with many constituents which are exposed to inhabitants of the city. In Lagos Nigeria, traffic congestion in the city is unquantifiable to any city in Africa, the city is home to over $60 \%$ of the industrial and commercial infrastructures of Nigeria and a population in excess of 20 million (Bureau of Statistics, 2013, Ajayi 2007 Oteri and Ayeni, 2016 and Nwagwu and Oni, 2015). These conditions have caused the problem of pollution in the city a perennial one. The inhabitants are continuously expose to emissions and fumes of particulates matter, nitrogen oxide, asbestos, carbon monoxide and incomplete hydro carbon combustion in the city (Akanni 2010). Also reported in the Guardian is the nexus between land use pattern and household vehicles by Frank et al (2000) in the Puget Sound region where an inverse relationship between household density, work tract employments density, street connectivity etc. and household vehicle emissions were discovered. There is a need for an investigation of the contribution of anthropogenic factors on urban air quality in Lagos Metropolis with a view to enunciating its spatial distribution over residential, commercial and industrial locations in the city.

\subsection{Conceptual Framework}

\subsubsection{Air Quality Index}

Air Quality Index (AQI) also known as air pollution index (API) or pollution standard index (PSI) has been developed by several agencies in Canada, USA, Australia, Europe, China, Taiwan and Indonesia etc. (Tiwari, 2015) adopted from (Shenfeld, 1970; Ott and Thom, 1976; Thom and Ott, 1976; Murena, 2004 Ott and Hunt, 1976; USEPA, 1994, Cairncross et al, 2007 and Cheng et al, 2007). According to Tiwari (2015) the pioneer of air quality indices was Green (1966) called the Green Index who made emphasis on Sulphurdioxide (SO2) and coefficient of Haze $(\mathrm{COH})$ as the mean for computing air pollution index. Several indices have emerged and have been used for the computation of air quality index. In historically succession they are; the Green Index by Green 1966, Ontario API by Shenfeld 1970, Oak Ridge Air Quality Index by the Oak Ridge National Laboratory (published by the ORAQI) of 1971, the United State Environmental Protection Agency air pollution index of 1976, the air quality depreciation index by (Sharma et al 1991) cited in (Tiwari 2015) and the new air quality index based on factor analysis by (Bishoi et al 2009) cited in Tiwari (2015).

Air Quality Index (AQI) is a tool that communicates information on air quality in qualitative terms (for example, good, satisfactory, poor) for citizens to be aware of associated health impacts and facilitates greater public participation in air quality improvement efforts. It is employed by cities, states, and countries around to the world to communicate present and future health risks of air pollution to residents. The AQI communicates simplified air pollution information based on data collected through national monitoring systems that may not always be collected or reported in a form that is understood easily by the public. Additionally, the AQI also provides detailed data on how to protect health from air pollution and to guide pollution-reducing policies and regulations. (Central Pollution Control Board, Non-Attainment, 2008). The AQI provides an index number for reporting daily air quality, on a scale from 0 to 500 . The higher the AQI value, the greater the level of air pollution that day, and the greater the potential health concerns. Typically, AQI values of 100 correspond to the national air quality standard for each pollutant, so AQI values of 100 or less are generally considered satisfactory. An AQI value of 50 would represent good air quality with low risks to public health, but an AQI value of 300 would represent air quality so hazardous that even healthy people may feel its respiratory effects (United States Environmental Protection Agency, AQI, 2014). The AQI serves as a communication bridge to members of the public that can summarize complex air quality information in a single number and associated color code. AQIs have variations in different locations and settings, but most AQI systems have two common characteristics: a table with different levels of air pollution and health risks, ranging from minimal to severe; and color-coding to distinguish these levels, also known as breakpoints. The breakpoints distinguishing different AQI levels are tied to the wealth of scientific, epidemiologic evidence that links air pollution to adverse health effects among specific vulnerable populations. As such, the communication of AQI information to members of the public also depends on the identification of specific target audiences that are especially vulnerable to air pollution (Ahmedabad, 2017).

An AQI summarizes a rating for the quality of the air city residents are breathing, and an associated level of potential health impacts. In situations where multiple air pollutants are monitored concurrently, the AQI typically 
reflects the air quality and associated health effects for the most dominant pollutant. The AQI is calculated through an analysis of local weather and outdoor air pollution data. AQI values tend to vary seasonally, and depending on the time of day. (Ahmedabad, 2017 and Tiwari 2015). To compute an Air Pollution Index, the United State Environmental Protection Agency Air Pollution Index developed in 1976 is stated below:

$\mathrm{I}_{\mathrm{p}}=\mathrm{I}_{\mathrm{HI}-} \mathrm{L}_{\mathrm{lo}} / \mathrm{BP}_{\mathrm{Hi}-\mathrm{BP}_{\mathrm{lo}}}\left(\mathrm{C}_{\mathrm{p}}-\mathrm{BP}_{\mathrm{lo}}\right)+\mathrm{I}_{\mathrm{lo}}$

$\mathrm{IP}=$ Index for pollutants

$\mathrm{Cp}=$ the rounded concentration of pollutants

$\mathrm{BPHi}=$ the breaking point that is greater than or equal to $\mathrm{Cp}$

$\mathrm{BPLo}=$ the break point that is less than or equal to $\mathrm{Cp}$

$\mathrm{IH}=$ the $\mathrm{AQI}$ value corresponding to $\mathrm{BPHi}$

$\mathrm{ILo}=$ the $\mathrm{AQI}$ value corresponding to BPLo

\subsubsection{Environmental Kuznets Curve (EKC)}

The Environmental Kuznets Curve (EKC) was propounded by Simon Kuznets in 1955 and hypothesized that income inequality first rises and then falls as economic development proceeds. It states that economic development initially leads to deterioration in the environment and after a certain level of economic growth, society begins to improve its relationship with the environment and levels of environmental degradation reduces. (Stern, 2003, Tejvan, 2017). The EKC hypothesis postulates an inverted-U-shaped relationship between different pollutants and per capita income, i.e., environmental pressure increases up to a certain level as income goes up and after that, it decreases. An EKC actually reveals how a technically specified measurement of environmental quality changes as the fortunes of a country change. Environmental quality deteriorates at the early stages of economic development/growth and subsequently improves at the later stages. In other words, environmental pressure increases faster than income at early stages of development and slows down relative to GDP growth at higher income levels (Soumyananda, 2004).

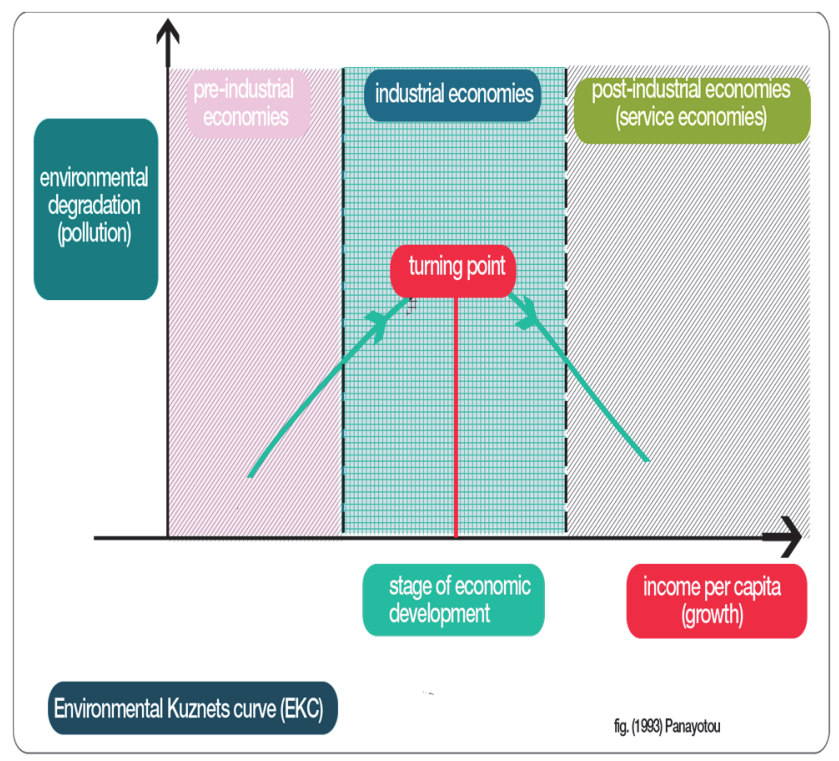

(Source: Tejvan , 2017; Soumyananda, 2004)

Figure 1. Environmental Kuznets Curve (EKC)

Some forms of pollution appear first to worsen and later to improve as countries incomes grow. The world's poorest and richest countries have relatively clean environments, while middle-income countries are the most polluted. Grossman and Krueger (1995) and the World Bank (1992) first popularized this idea, using a simple empirical approach. They regress data on ambient air and water quality in cities worldwide on a polynomial in GDP per capita and other city and country characteristics. They then plot the fitted values of pollution levels as a function of GDP per capita, and demonstrate that many of the plots appear inverse-U-shaped, first rising and then falling. 
Researchers have examined a wide variety of pollutants for evidence of the EKC pattern, including automotive lead emissions, deforestation, greenhouse gas emissions, toxic waste, and indoor air pollution (Levinson 2000).

\section{Review of the Literature}

\subsection{Seasonal Variation in Air Pollutants Levels}

Akanni (2010) examined biannually the spatial-seasonal analyses of traffic related pollutant concentrations in Lagos metropolis with emphasis on land uses (commercial, residential, industrial, institutional, parks, incinerators and transportation) along traffic corridors with six stations located $250 \mathrm{~m}$ away as control during the short wet and dry seasons. Thirty-four sampling points were randomly selected with dominance of Terminalia Catappa L (Almond) trees. Leaf samples were analyzed to identify and quantify for the concentration of trace elemental pollutants: ( $\mathrm{Pb}, \mathrm{Cd}, \mathrm{Cu}, \mathrm{Cr}, \mathrm{Al}, \mathrm{Zn}, \mathrm{As}, \mathrm{Hg}, \mathrm{Fe}, \mathrm{Mn}$, and $\mathrm{Mg}$ ). He discovered that the microclimate of Lagos metropolis was characterized by relatively high air temperature, low wind speed and air pollution with marked differences according to traffic density and land-uses. Gobo, et al (2012) examined the comparative variation between air quality and noise around Okirika communities in rivers state Nigeria using a Portable digital Industrial scientific corporation ITX multi gas monitor, Aerosol mass monitor and Digital Cole Parmer combination(Hydrothermo-Anenometer) and their results revealed a highest concentrations of $0.007 \mathrm{mg} / \mathrm{m} 3$ (PM1, dry), $0.036 \mathrm{mg} / \mathrm{m} 3\left(\mathrm{PM}_{2.5}\right.$, dry), 0.286mg $/ \mathrm{m} 3$ ( $\mathrm{PM}_{7}$, dry), $0.378 \mathrm{mg} / \mathrm{m} 3\left(\mathrm{PM}_{10}\right.$, dry), $0.503 \mathrm{mg} / \mathrm{m} 3$ (TSP, dry), $1.7 \mathrm{ppm}\left(\mathrm{NO}_{2}\right.$, dry), 3.0ppm $\left(\mathrm{CH}_{4}\right.$, dry),0.2ppm $\left(\mathrm{H}_{2} \mathrm{~S}\right.$, dry), 12.7ppm (CO, dry), 2.7ppm $\left(\mathrm{NH}_{3}\right.$, dry), and 7.0ppm (VOC, rainy). The dry season concentrations of pollutants were considerably higher than the rainy season concentrations and the noise pollution levels were very high too.

Asuoha and Osu (2015) investigated the seasonal variation of meteorological factors and the impacts of gas flaring on air quality in the Delta Niger area(Ibeno,Onaa,Esit Eket and Umudike) and discovered a strong positive correlation between air quality parameters(Cl-,SPM and SO2) and meteorological factors(vapour pressure, relative humidity, temperature and precipitation) in the area. Asubiojo (2016) and Taiwo et al (2015) enumerated the major sources of pollution in Nigeria as natural (e.g. harmattan dust, sea spray and decaying vegetation) and anthropogenic (e.g. industry, mining, vehicular emissions, solid waste disposal, agricultural practices, power generation and domestic practices. Lucidly, Offor et al (2016) created a distinction in the composition of particulate matter in Nigeria in retrospect by examining elemental composition of aerosols at selected locations in Nigeria from 1985-2015 and confirmed that PM2.5 concentrations ranged between 5-248 $\mu \mathrm{g} / \mathrm{m}^{3}$, while $\mathrm{PM}_{10}$ concentration ranges between $18-926 \mu \mathrm{g} / \mathrm{m}^{3}$, revealing that about $50 \%$ of the particulate matter loads in Nigeria exceeded both the WHO $\left(25 \mu \mathrm{g} / \mathrm{m}^{3}, 50 \mu \mathrm{g} / \mathrm{m}^{3}\right)$ and NAAQS $\left(35 \mu \mathrm{g} / \mathrm{m}^{3}, 150 \mu \mathrm{g} / \mathrm{m}^{3}\right)$ guideline limits for $\mathrm{PM}_{2.5}$ and $\mathrm{PM}_{10}$, respectively. Most of the PM 2.5/PM 10 ratios in Nigeria fell below the 0.5 mark, implying that particulate matter in Nigeria is dominated by coarse, rather than fine particles. In addition, particulate matter loads in rural areas were generally lower than their corresponding loads in urban areas. Wind-blown dust from the Sahara Desert is the major contributor to particulate matter loads in northern Nigeria, while sea spray and crustal matter are highest contributors to particulate matter loads in the southern Nigeria.

In the Niger delta region, Ana (2011) and Ogwu et al (2015) investigated the scopes, challenges and remedies to air pollution bedeviling the Niger delta region and enumerated that traffic, industry and gas flaring as the major air pollution sources. Multiple factors especially lack of equipment, inadequate skilled personnel and poor policy frame work have militated against effective and qualitative air quality studies in the area where cancer of the skin is becoming an emerging health challenge amongst the inhabitants. Weli and Adegoke (2016) also investigated the influence of meteorological parameters and land use on the seasonal concentration of Carbon monoxide in Port Harcourt city using multiple linear, step wise multiple linear regression and ANOVA and revealed that the commercial areas of Creek Road, Mile III market and densely populated residential areas of Diobu and Rumuagholu had high concentrations of CO with areas like Nkpogu,Woji, Elenlewo, Aleto, Alesa, Ogonigba and Rumuomasi experiencing high urban heat island effects(temperature rise) than the GRAs and the Abuloma housing estates.

\subsection{Air Quality Monitoring}

Different instrument and techniques have been used in the monitoring of air pollution globally. Gang et al., (2016) Spatio temporarily examined the impacts of land use on air quality in Wuhan China using buffering for the demarcations of sites, bivariate correlation to test for the relationship between land use variables and annual average concentrations of air pollutants, stepwise linear regressions for modeling and the Leave Out One Cross Validation (LOOCV) techniques to test for the performance of the regression model. In Nigeria, Ipeaiyeda and Adegboyega (2017) examined the concentration of pollutants at major road intersections in Ibadan city with focus on $\mathrm{SO}_{2}, \mathrm{NOx}, \mathrm{O}_{3}, \mathrm{NH}_{3}$ and $\mathrm{CO}$ using the absorption train technique which involves the absorption of pollutant gas 
from air into a reagent solution. The absorption train consists of various components which consist of a set of flow rate calibrated critical orifices and impingers. Umoh et al (2013) used a vital graph spirometer model to measure forced expiratory volume and the forced vital capacity to test for indoor pollutants effects amongst fisher men in Ibok and Ibaga communities of Nigeria. Nwachukwu et al (2012) investigated the effect of air pollution on diseases in Rivers State, analyzing epidemiological data from the State Ministry of Health. Akanni (2010) used thirty-four (34) samples of Terminalia catappa L (Almond) trees to investigate the spatio seasonal pollutants concentration along traffic corridor in Lagos metropolis. Ediagbonya and Tobin (2013) used the SKC gravimetric sampler to capture inhalable and respirable fractions of fine particulate matter in sapele delta state. Ekpenyong et al (2012) used anthropometric (weight $(\mathrm{kg})$, height $(\mathrm{m})$ and body mass index), Spiro metric (lung function capacities e.g. force vital capacity (FVC), air quality measures (Aerosol monitor 'DUST TRACK model 8520 (TS1 Inc., Minnesota, USA) and statistical techniques (descriptive analysis, analysis of variance (ANOVA), chi-square, and multiple logistic regressions) to test for the association between exposure to outdoor ambient air pollution and its risk factors. Multiple logistic regression analysis showed significant association between occupational exposure to ambient air pollution and duration on job smoking habits and number of trip per day and transit time in CMCs and TDs.

\subsection{Air Quality Analysis}

Xiaolin et al (2017) used general additive model (GAM) (for exploring and fitting nonlinear relationships between a responds and predictor variables) to explore the association between air pollution and its effects on respiratory health in Shenzhen china. Combined with the distributed lag model (DLM) to examine the lag effect of air pollutants since pollutants effects are not limited to the exposure period alone but the lag times. Other variables considered were weather effects on pollutants concentrations (temperature, pressures and relative humidity). The smoothing spline functions of calendar time was added to adjust for long term trends and control and the generalized cross validation to guide the determination of the degree of freedom for minimal sum of errors. The degree of freedom (df) of the smoothing functions were determined by the Akaikes information criterion, a dummy variable for days of the week and a time series analysis in terms of the acute upper and lower respiratory infections were included. Their findings discovered that for acute upper respiratory infection, significant associations were only observed for patients under 14 years with $\mathrm{PM}_{10}$ and $\mathrm{PM}_{2.5}$ and for acute lower respiratory infection, significant associations were observed for patients under 14 years and patients aged from 15 to 64 years with both $\mathrm{PM}_{10}$ and $\mathrm{PM}_{2.5}$, and for patients under 14 years and patients above 65 years with $\mathrm{NO}_{2}$.A non-linear exposureresponse curve capturing the relationship between air pollutant concentration and the number of acute respiratory infection hospitalization showed that air pollutant revealed significant adverse effects on respiratory health when exceeding a threshold concentration. The study presented the strongest evidence connecting air pollutants with adverse health effects for $\mathrm{PM}$ and $\mathrm{NO}_{2}$.

Jenq-Hwan et al (2017) investigated the impacts of ambient particulate matter exposure on tuberculosis incidences in Taipei city Taiwan using evidence-based exposure assessment of particulate matter by connecting monthly TB incidences and coarse/fine particulate matter concentrations from 2009 to 2016 and 2006 to 2016.Pearson correlation coefficients were used to analyze the correlation between TB incidence and cumulative average air pollutant concentration. Tuberculosis incidence tended to be most correlated with the average concentration of PM 10 and $\mathrm{PM}_{2.5}$, respectively at 32-, and 8-month. Their findings on correlation analysis showed periodic fluctuation which was similar with the seasonal concentration of particulate matters. Amit et al (2015) successfully established the association between quarterly/seasonal air pollution exposure and asthma using the geospatial approach in India by Linking seasonal exposure of air pollution levels and asthma hospital discharge rate (ADR) through estimating the pollutants concentration profile and ADR profile and constructing a spatial model using quarterly average pollutant concentration data and ADR data. Point correlation, auto correlation and cross correlation analyses were employed and their results elucidated a uniform trend in the associations between quarterly exposure of air pollution ( $\mathrm{PM}_{2.5}, \mathrm{NO}_{2}$, and $\mathrm{O}_{3}$ ) and quarterly asthma discharge rate (ADR). A positive correlation coefficient was consistently observed between the quarterly mean concentration of $\mathrm{PM}_{2.5}$ and the quarterly asthma discharge rate. Also, a negative correlation coefficient was observed between the quarterly mean concentration of $\mathrm{NO}_{2}$ and the quarterly asthma discharge rate. Their findings enunciated a better understanding of the nexus between seasonal air pollution exposure and seasonal asthma discharge rate and identified $\mathrm{PM}_{2.5}$ as the major cause of the asthma discharge rate (ADR). Prior to this,Choi, et al (2007) investigated the association between exposure to seasonal ambient air pollution and blood pressure in South Korea using multiple regression analysis by examining 10459 subjects from 2001 to 2003 and discovered that coarse particulate matter and nitrogen(iv)oxide were positively related to measures of blood pressure, also sulphur(iv)oxide and ozone concentration were associated with blood pressure during the cold season as coarse particulate matter and nitrogen(iv)oxide were negatively related to blood 
pressure during the cold season and concluded a seasonal variation in ambient air pollution to be associated with blood pressure.

In Nigeria, Alfred and Hyeladi (2013) evaluated the association between traffic related pollutants and diseases in Jos, Plateau State analyzing trend in vehicle traffic pollution and data for asthma, cardiovascular and bronchitis for a decade (2002-2011). Their findings revealed a simultaneous increase in vehicle emission and incidences of cardiovascular, asthma and bronchitis. In River state Nigeria, Nwachukwu et al (2012) evaluated the effect of air pollution on diseases spread by analyzing epidemiological data collected from the State Ministry of Health, and found pertussis, pulmonary tuberculosis, cerebrospinal meningitis, pneumonia, measles, chronic bronchitis, and upper respiratory tract infection to be incident as a result of air pollution. The ambient air quality indicated that $\left(\right.$ lead $=0.1115 \mathrm{ppm} /$ year, particulates $=10 \mathrm{ppm} /$ year, N-oxides $=2.55 \mathrm{ppm} /$ year, $\mathrm{SO}_{2}=1 \mathrm{ppm} /$ year, $\mathrm{VOC}=82.78$ $\mathrm{ppm} /$ year) were far worse than the World Health Organization Air Quality Standard (Lead = $1 \times 10-6 \mathrm{ppm} / \mathrm{year}$, particulates $=105 \mathrm{ppm} /$ year). They advised that intensification of environmental education among rural dwellers was the panacea to overcoming pollution problems.Umoh et al (2013) examined the long term respiratory effects of indoor air pollution amongst fisher men in Ibaka and Ikang communities in cross river and akwa ibom states in the Niger delta area of Nigeria using a modified British Medical Council respiratory disease questionnaire (BMRC) translated into the local dialect and administered to five hundred and twenty-one fishermen exposed to indoor air pollution and 545 control subjects in order to elicit information on chronic bronchitis, wheezing, shortness of breath and cigarette smokers. The presence of chronic bronchitis among test subjects exposed to firewood smoke reported more episodes of chronic phlegm production, difficulty in breathing, wheeze and chronic bronchitis than the control.

Ekpenyong et al., (2012) carried out an assessment and comparison of respiratory health effects of ambient air pollutants on transit commercial motor cyclist(CMC) and taxi drivers(TD) and non-transit workers (civil servants) in Uyo metropolis and revealed a significant difference in height, body mass index, educational statues, area of residence, exposure to biomass, physical activity, transit time and number of trips per day between the three occupations at $\mathrm{p}<0.001$. The odds for impaired respiratory functions following occupational exposure to ambient air pollution was highest in CMC whereas no difference was observed in the odds between the two groups of transit workers. The prevalence of respiratory functions impairment was highest among transit than non-transit workers.

\section{Methods}

\subsection{Lagos}

\subsection{History}

Historically Lagos was christened in 1472 as Lago de Curamo which means lakes by a Portuguese sailor named Ruy de Sequeira, prior to this it was named Eko by the Binis who governed the town in the sixteenth century as a trade, fishing and sea port center. Precolonial times described the town as farming and fishing center and an arterial route for the birth and export of slaves in the eighteenth century, during the colonial time Lagos became a prominent province for colonial rule and assumed a higher economic and political status due to its strategic location. It was the capital of Nigeria from independence to the $12^{\text {th }}$ of December 1991 when the capital of Nigeria was moved to the hinterland region of Nigeria at Abuja and despite this Lagos has remained the economic and commercial lifeline of Nigeria (Akunnaya and Adedapo, 2014).

\subsection{Location and Areal Extent}

Lagos state is bounded by Ogun state to the north and east and the republic of Benin to the west with over $180 \mathrm{~km}$ coast line of the Atlantic. Lagos state has a landmass of over 3345sq.km and metamorphoses from five administrative divisions of Ikeja, Ikorodu, Lagos Island, Epe and Badagry to 20 Local Government Areas (LGAs) and presently redefined by the state government to thirty-seven (37) Local council development areas (LCDA) including the 20 LGAs to form a total of 57 local council administrative units. From these units comprise notable areas like Somolu, Oworoshoki, Isolo, Ikotun, Agege, Ijulshaga, Egbeda, Ketu, Bariga, Ajah, Ejogbo, Ipaja, Maryland and Mushin etc.

\subsection{Climate}

The climatic condition of the state is defined by the tropical monsoon climate (Am) with marked dry and wet seasons that spans within the period of April to July $(400 \mathrm{~mm})$ and October to November $(200 \mathrm{~mm})$ and from August to March for the dry season with intermittent diurnal showers between Septembers to December. With a diurnal average temperature of $37.3^{\circ} \mathrm{C}$ and a minimum of $57^{\circ} \mathrm{C}$, the state is waters by rivers, streams and lagoons and drained by a complex river basin shaped like the Caspian Sea (Oteri and Ayeni, 2016 and Nwagwu and Oni 
2015). Geologically underlain by sedimentary rocks on a coastal plain and blessed with flat terrain which slopes from the hinterland to the coast with average elevation of less than $15 \mathrm{~m}$ above mean sea level. The landscape of the city is defined by $40 \%$ of wetlands and water bodies and $22 \%$ of lagoons and creeks suitable to seasonal flooding at the rate of $12 \%$ (Oteri and Ayeni, 2016).

\subsection{Population and Demography}

The population of Lagos slowly grew from 267,400 in 1952 to over 670,000 at the rates of $8.6 \%$ in 1963 and in 1995 it geometrically increased to $6.5 \mathrm{~m}$ making her the $29^{\text {th }}$ largest city in the world according to the United Nation Statistics report of 2000. Its reached $8.8 \mathrm{~m}$ and $10 \mathrm{~m}$ in 2005 making her one of worlds mega cities and became the $19^{\text {th }}$ most populated world city in 2011 with a population of $11.2 \mathrm{~m}$ and projected to hit the $19 \mathrm{~m}$ mark by 2025 (Akunnaya and Adedapo, 2014).

Currently Lagos has a population of $15 \mathrm{~m}$ and growth rates of $4.19 \%$ according to the National Bureau of Statistics, World Urbanization Prospects and the Nigerians Population Commission Fact Sheet Report (2017). Lagos is the commercial and economic nerve center of Nigeria with a growth rate of $3.2 \%$, urbanization rates of $16 \%$, GDP of $\$ 33.679$ billion and per capita income of $\$ 4.333$, population density of 20,000 per square kilometers and daily immigrants of over 3000 people.

\subsection{Housing Styles and Problems}

Housing difficulties are enormous, far reaching and deficits in both quantity and quality with $72 \%$ of residents paying over half of their monthly income as rents controlled largely by private landlords while other dwellings accounts for $10 \%$ as free occupants and $18 \%$ as owner occupiers (Economic Intelligence Unit, Issue 1, 2012). These obvious disadvantages in housing has led to the developments of slums, shanties, quarter settlements and ghettoes characterized by poverty, deprivation, crime, violence, environmental pollution, inadequate access to basic social services, general human insecurity and life-threatening diseases and risks (Akunnaya and Adedapo, 2014). Lagos metropolis is currently grappling with the perennial problem of traffic congestions along major roads in the mornings and the evenings. The major residential areas are Mushin, Surulere, Agege, Oshodi, Yaba and Ikeja, the capital of the state and the elitist areas of Ikoyi, Victoria island, Apapa and Lekki Peninsula layout domiciled by individuals of very high social status which comprises of the rich expatriates, high ranking government officials, captains of industries and trillionaires in different styled housing made up of detached bungalows, semi duplexes and mansions etc. (Oludayo et al, 2011).

\subsection{Economic Potentials}

Ajayi, (2007) evaluation of the patterns and locations of industrial development in Nigeria revealed a skew in the locations of industries to Lagos alone hosting over $50 \%$ of the industrial assets of Nigeria ranging from electronics, telecommunications, food and beverages, chemicals, manufacturing, banking and diplomatic establishments. This is consistent with the South West Investment Exhibition and Summit(SWIFT) report of 2017 which stated that South Western Nigeria and Lagos especially controls $60 \%$ of the nation's industrial capacity, $44 \%$ of banking assets, $67 \%$ of insurance assets and diplomatic assets and a host to the nation's three deep sea ports of Apapa, Tin Can island and Roro,the busiest international airport of Ikeja, a connection to the three thermal stations of Egbin, Papalanto and Omotosho and the West African Gas Pipeline linked industrial estates of Agbara, Ikeja and Otta under the West African Gas Pipeline Plan, the most economically solvent state with a GDP per capital income of over 450.87 billion naira monthly, generating over $75 \%$ of the states internally generated revenue (Lagos State Ministry of Budget, 2017) and a landscape defined by the presence of Eko, Carter and the third mainland bridges connecting the island to the main land (Nwagwu and Oni 2015). 


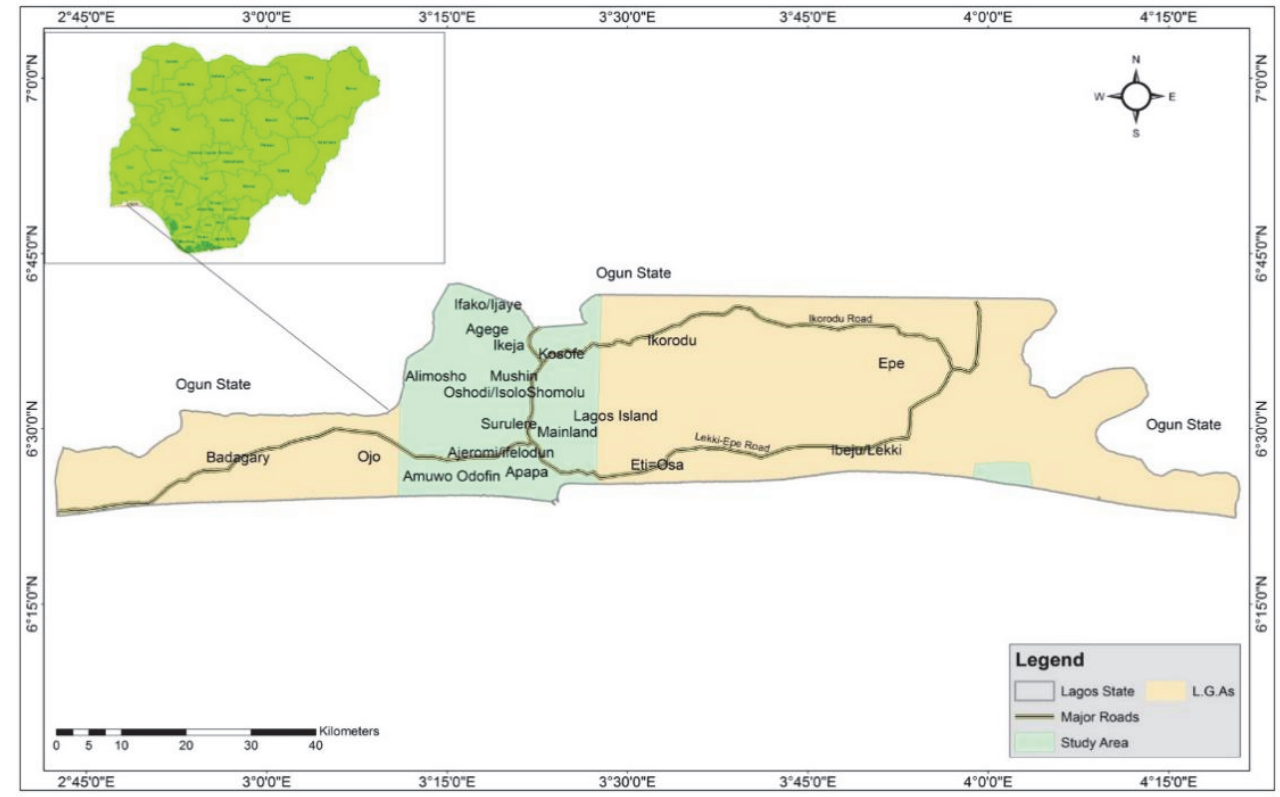

Figure 2. Metropolitan City of Lagos

\section{Data Collected}

Secondary data which comprises of air quality indicators for carbon(iv)oxide, fine particulate matter, sulfur(iv)oxide and nitrogen(iv)oxide were used for this research for the year 2010 to 2013 and sourced from the Lagos State Ministry of Environment, Ikeja. Other information were sourced from journals/articles literature etc.

\subsection{Site Description}

Thirty points from the densely populated and built-up areas of Lagos were selected and divided in to residential, commercial and industrial points for this study as shown on table 1 to table 3 and figure 2 . The hardware deployed for this work are computer laptop for processing, collating, recording and manipulating of the acquired data and software's also are Microsoft offices packages containing word, power point and excel for data analysis and representation of charts, hypotheses testing, and manipulations. Others are Arc GIS 10.4 for mapping and representation of the spatial distribution of the pollutants concentrations.

Table 1. Residential Land use

\begin{tabular}{llll}
\hline S/n & Location/Sampling Points & $\begin{array}{l}\text { Latitudinal } \\
\text { Co-ordinates }\end{array}$ & $\begin{array}{l}\text { Longitudinal } \\
\text { Co-ordinates }\end{array}$ \\
\hline & Ogba Housing Estate & $6^{0} 34.634 \mathrm{~N}$ & $3^{\circ} 20.673 \mathrm{E}$ \\
2 & Ikeja GRA,Ikeja & $6^{0} 34.634 \mathrm{~N}$ & $3^{\circ} 21.313 \mathrm{E}$ \\
3 & Magodo Estate,Kosofe & $6^{0} 36.605 \mathrm{~N}$ & $3^{\circ} 22.308 \mathrm{E}$ \\
4 & Agege Housing Estate & $6^{0} 38.332 \mathrm{~N}$ & $3^{\circ} 19.210 \mathrm{E}$ \\
5 & Iba Housing Estate,Ojo & $6^{0} 29.438 \mathrm{~N}$ & $3^{\circ} 11.817 \mathrm{E}$ \\
6 & Unity Estate,Alimosho & $6^{0} 35.099 \mathrm{~N}$ & $3^{\circ} 22.308 \mathrm{E}$ \\
7 & Mile2 state,Amuwo,Odofin & $6^{0} 27.903 \mathrm{~N}$ & $3^{\circ} 18.554 \mathrm{E}$ \\
8 & Forest shore Estate,Eti-Osa & $6^{0} 27.916 \mathrm{~N}$ & $3^{\circ} 25.674 \mathrm{E}$ \\
9 & Beachland Estate,Apapa & $6^{0} 26.277 \mathrm{~N}$ & $3^{\circ} 13.318 \mathrm{E}$ \\
10 & Adekunle Estate,Yaba & $6^{0} 29.499 \mathrm{~N}$ & $3^{\circ} 23.157 \mathrm{E}$ \\
\hline
\end{tabular}

Source: Ministry of Environment, Lagos State 2014 
Table 2. Commercial Land Use

\begin{tabular}{lllll}
\hline S/n & Location/Sampling Points & $\begin{array}{l}\text { Latitudinal } \\
\text { Co-ordinates }\end{array}$ & $\begin{array}{l}\text { Longitudinal } \\
\text { ordinates }\end{array}$ & Co- \\
\hline 1 & Maryland Junction, Ikeja & $6^{\circ} 34.306 \mathrm{~N}$ & $3^{\circ} 22.069 \mathrm{E}$ \\
2 & $\begin{array}{l}\text { Ikeja General Hospital Frontage, } \\
\text { Ikeja }\end{array}$ & $6^{\circ} 35.510 \mathrm{~N}$ & $3^{\circ} 20.589 \mathrm{E}$ \\
3 & Pencinema Junction, Agege & $6^{\circ} 37.701 \mathrm{~N}$ & $3^{\circ} 19.466 \mathrm{E}$ \\
4 & CMS Bus Stop, Lagos Island & $6^{\circ} 27.022 \mathrm{~N}$ & $3^{\circ} 23.352 \mathrm{E}$ \\
5 & Iyana Iba Bus Stop, Ojo & $6^{\circ} 27.640 \mathrm{~N}$ & $3^{\circ} 12.275 \mathrm{E}$ \\
6 & Iyana Ipaja Bus Stop, Agege & $6^{\circ} 37.143 \mathrm{~N}$ & $3^{\circ} 18.083 \mathrm{E}$ \\
7 & Ojodu Berger Bus Stop, Ikeja & $6^{\circ} 38.388 \mathrm{~N}$ & $3^{\circ} 22.229 \mathrm{E}$ \\
8 & Oshodi Bus Stop, Oshodi-Isolo. & $6^{\circ} 33.294 \mathrm{~N}$ & $3^{\circ} 21.115 \mathrm{E}$ \\
9 & Ajegunle Junction, Apapa. & $6^{\circ} 27.294 \mathrm{~N}$ & $3^{\circ} 21.053 \mathrm{E}$ \\
10 & Mushin Bus Stop, Mushin & $6^{\circ} 31.813 \mathrm{~N}$ & $3^{\circ} 21.195 \mathrm{E}$ \\
\hline
\end{tabular}

Source: Ministry of Environment, Lagos State 2014

Table 3. Industrial Land Uses

\begin{tabular}{|c|c|c|c|}
\hline $\mathrm{S} / \mathrm{n}$ & Location/Sampling Points & $\begin{array}{l}\text { Latitudinal } \\
\text { Co-ordinates }\end{array}$ & Longitudinal Co-ordinates \\
\hline 1 & Ikeja Industrial Area, Ikeja & $6^{\circ} 36.683 \mathrm{~N}$ & $3^{\circ} 20.372 \mathrm{E}$ \\
\hline 2 & Wempco Road, Ikeja & $6^{\circ} 37.370 \mathrm{~N}$ & $3^{\circ} 20.302 \mathrm{E}$ \\
\hline 3 & Wemabod, Ikeja & $6^{0} 36.477 \mathrm{~N}$ & $3^{\circ} 19.927 \mathrm{E}$ \\
\hline 4 & Agbara Industrial Area & $6^{0} 30.419 \mathrm{~N}$ & $3^{\circ} 05.756 \mathrm{E}$ \\
\hline 5 & Matori Industrial Area, Mushin & $6^{\circ} 32.455 \mathrm{~N}$ & $3^{\circ} 20.822 \mathrm{E}$ \\
\hline 6 & Tincan Port, Apapa & $6^{\circ} 26.130 \mathrm{~N}$ & $3^{\circ} 21.312 \mathrm{E}$ \\
\hline 7 & Sabo, Yaba. & $6^{0} 30.274 \mathrm{~N}$ & $3^{\circ} 22.989 \mathrm{E}$ \\
\hline 8 & Kirikiri, Apapa & $6^{\circ} 26.996 \mathrm{~N}$ & $3^{\circ} 23.247 \mathrm{E}$ \\
\hline 9 & Tomjones, Lagos Island & $6^{\circ} 27.500 \mathrm{~N}$ & $3^{\circ} 23.247 \mathrm{E}$ \\
\hline 10 & Free Trade Zones, Ibeju Lekki. & $6^{\circ} 26.267 \mathrm{~N}$ & $3^{\circ} 57.349 \mathrm{E}$ \\
\hline
\end{tabular}

Source: Ministry of Environment, Lagos State 2014

\section{Results and Discussions}

Pollutant concentrations were at variance over the different land uses during the period of 2010 to 2013 for Carbon (ii) oxide $(\mathrm{CO})$, Fine particulate matter $\left(\mathrm{PM}_{2.5}\right)$, Sulfur (iv)oxide $\left(\mathrm{SO}_{2}\right)$ and Nitrogen(iv)oxide $\left(\mathrm{NO}_{2}\right)$ as showed in figure 3 to 6 . 


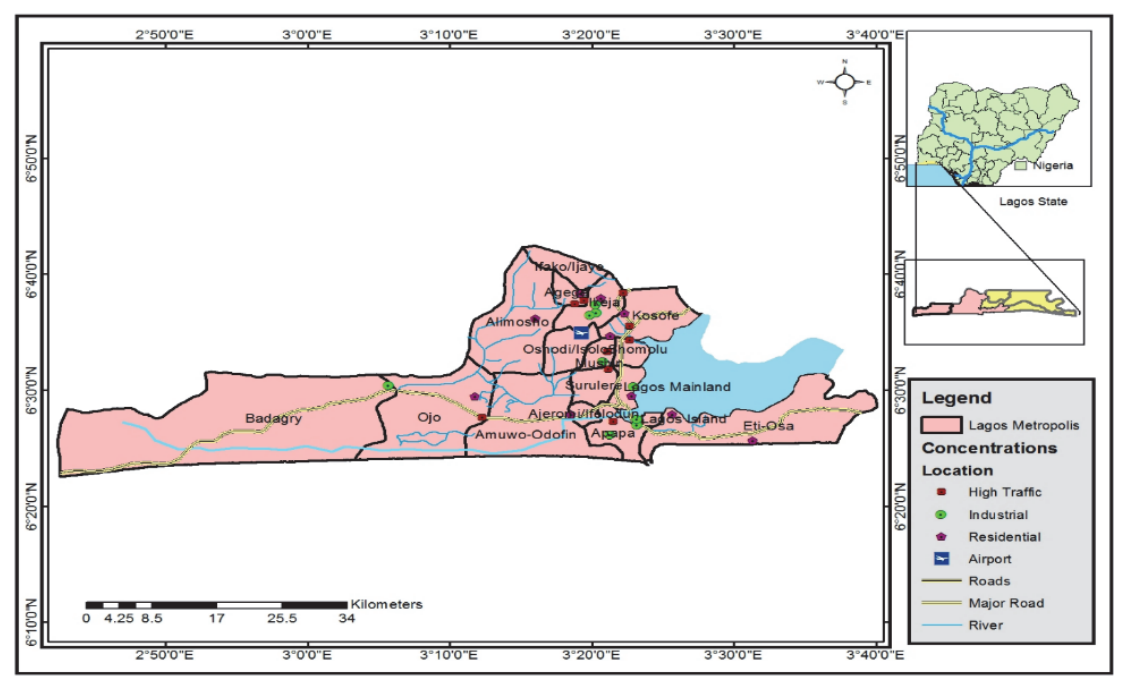

Figure 3. Residential, Commercial and Industrial Points in Lagos Metropolis

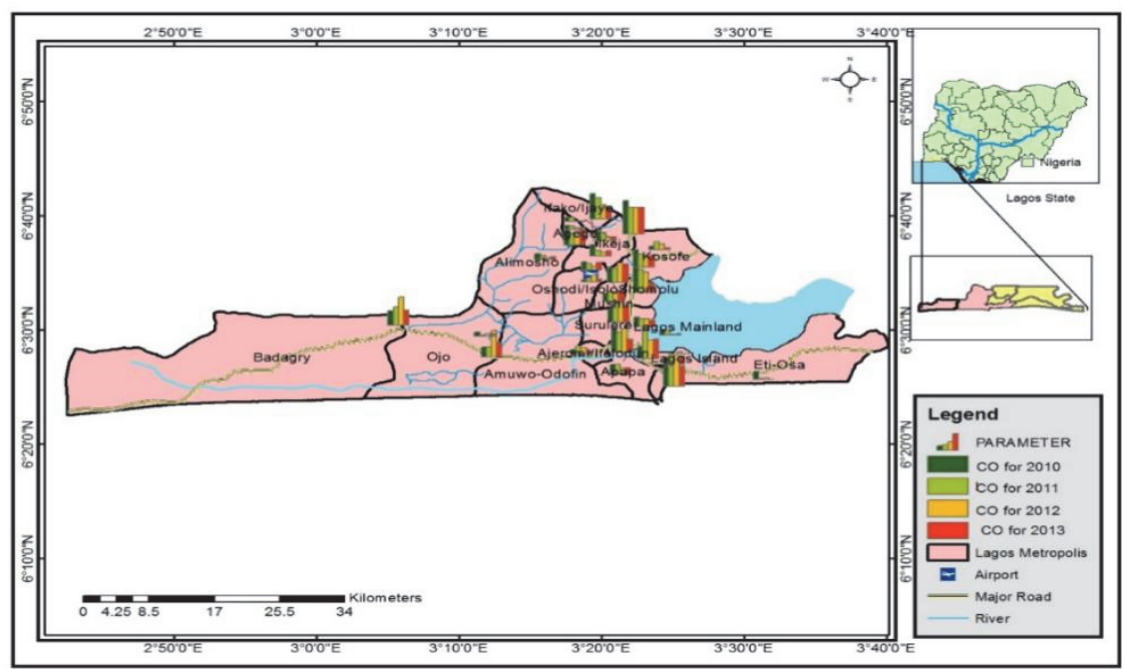

Figure 4. Spatial Variation of Carbon (II) Oxide Over Land Uses Between 2010-2013

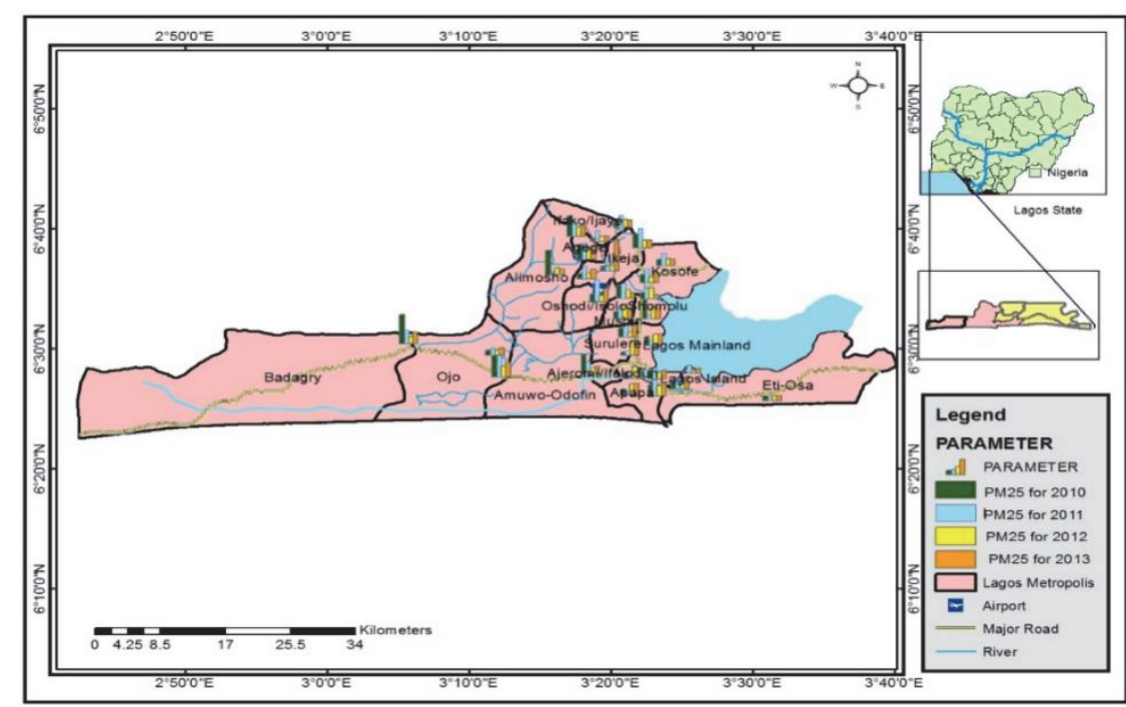

Figure 5. Spatial Variation of Fine Particulate Matter Over Land Uses Between 2010-2013 


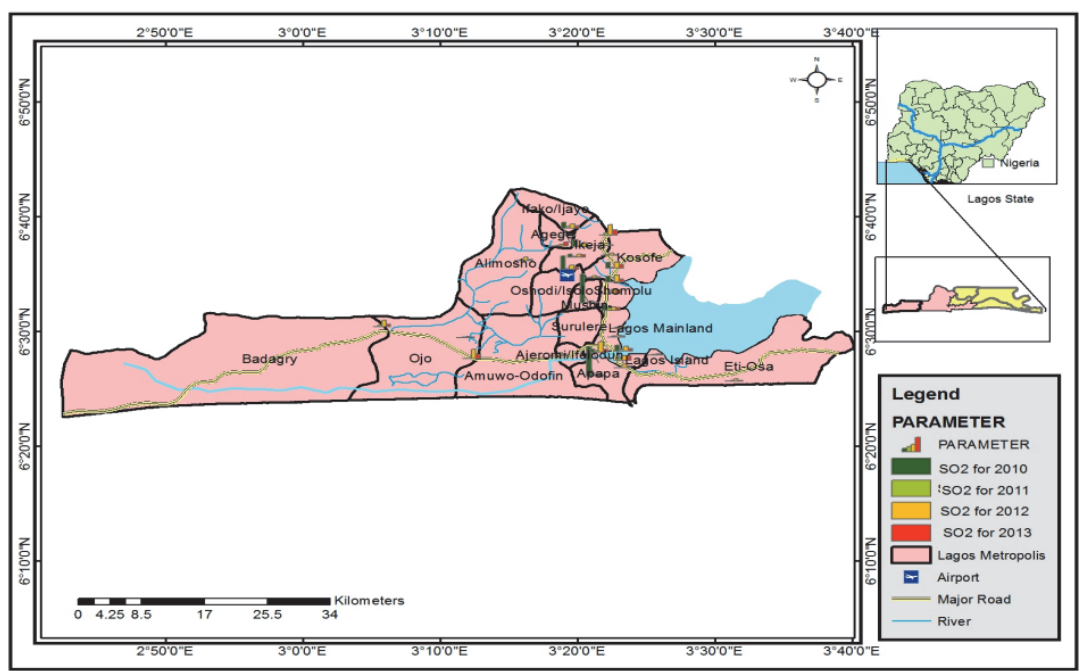

Figure 6. Spatial Variation of Sulfur (IV) Oxide Over Land Uses Between 2010-2013

\subsection{Carbon (II) Oxide (CO)}

The residential areas of Magodo Estate, Unity Estate, Alimosho, Adeyinka Estate and Beach Land Estate Apapa as shown in figure 4 in the appendix section revealed CO levels at $0.9 \mathrm{ppm}, 1.4 \mathrm{ppm}, 1.3 \mathrm{ppm}$ and $2.0 \mathrm{ppm}$. At Agege housing estate $0.1 \mathrm{ppm}$ was recorded while other residential areas showed between $0.6 \mathrm{ppm}$ to 1 . $0 \mathrm{ppm}$. The commercial areas which comprises of Ojodu Begger, Maryland Junction and Pen Cinema Junction recorded levels of pollutants at 7.8ppm and 6.0ppm while other locations such as Iyana Ipaja bus stop, Ikeja general hospital and CMS bus stop recorded $\mathrm{CO}$ levels at $4.7 \mathrm{ppm}, 4.0 \mathrm{ppm}$ and $4.8 \mathrm{ppm}$ with other commercial points recording between 2.3 to $3.4 \mathrm{ppm}$. In the industrial areas which comprises of Agbara, Wemabod, Tomjones and others CO levels revealed concentrations at 3.3ppm, 2.7ppm, 2.3ppm, 1.6ppm and 2.0ppm. Marked variations in 2011 however revealed an upward trend in Magodo estate where high concentrations of $\mathrm{CO}$ was discovered at $2 \mathrm{ppm}$ and a decline in other residential areas showing between 0.3 to $1.8 \mathrm{ppm}$. In the commercial points sampled Ojodu Begger revealed high levels at $6.2 \mathrm{ppm}$ while between $5.3 \mathrm{ppm}$ to $2.3 \mathrm{ppm}$ where discovered at Maryland, Pen cinema, Mushin bus stop, Ajegunle and CMS bus stop.

The industrial areas in 2011 showed between 7.6ppm to 1.6ppm at Tomjones Lagos Island, Agbara industrial estate and the other industrial areas. The residential areas in 2012 revealed a decline from the 2011 records which showed Ikeja GRA, Magodo estate and others at between $1.7 \mathrm{ppm}$ to $0.6 \mathrm{ppm}$. High levels were as expected recorded in the commercial areas with notable areas like CMS and Iyana Iba bus stop recording between $6.2 \mathrm{ppm}$ to $2.2 \mathrm{ppm}$ and the industrial areas recording between 3.5ppm to $1.0 \mathrm{ppm}$ with a peak at Agbarra Industrial Estates. The drop in $\mathrm{CO}$ levels in residential also continues in 2013 to record at between 0.2 to $0 \mathrm{ppm}$, commercial at a peak of $6.2 \mathrm{ppm}$ at oshodi bus stop and between 4.8ppm to 2. 0 ppm recorded at CMS Iyana Ipaja bus stop, Ajegunle, Mushin bus stop and others.

The reason for the high levels of carbon(iv)oxide in commercial and industrial areas is due to release of emmision from generating sets, traffic congestion and industrial chimney. This result corroborates with the findings of Akanni (2010), (Weli 2014), (Alfred and Hyadi 2013) and (Nwachukwu et al 2012), who reported elevated levels of carbon(iv)oxide along traffic corridors of Lagos, Portharcourt and Jos metropolis. Consistent with this is the concept of environmental kuznet curve which stated that development of economic activities are precursors to elevated levels of pollutants.

\subsection{Fine Particulate Matter (PM2.5)}

Fine particulate matter recorded in micrograms per cubic meters $\left(\mu \mathrm{g} / \mathrm{m}^{3}\right)$ in figure 5 showed that in 2010 between $60 \mu \mathrm{g} / \mathrm{m}^{3}$ to $5 \mu \mathrm{g} / \mathrm{m}^{3}$ were recorded at Ikeja GRA, Unity estate, Mile-2 Estate Amuwo Odofin and other residential points while the commercial areas sampled revealed higher concentration with a peak at Iyana Iba bus stop at $66 \mu \mathrm{g} / \mathrm{m}^{3}$ and between $50 \mu \mathrm{g} / \mathrm{m}^{3}$ to $15 \mu \mathrm{g} / \mathrm{m}^{3}$ accounting for other commercial areas. The industrial areas recorded a peak of $71 \mu \mathrm{g} / \mathrm{m}^{3}$ at Agbara industrial estate and between $15 \mu \mathrm{g} / \mathrm{m}^{3}$ to $25 \mu \mathrm{g} / \mathrm{m}^{3}$ for other industrial areas. The residential points in 2011 showed a decline in PM levels with a little peak at Ikeja GRA revealing $37 \mu \mathrm{g} / \mathrm{m}^{3}$ and between $31 \mu \mathrm{g} / \mathrm{m}^{3}$ to $10 \mu \mathrm{g} / \mathrm{m}^{3}$ for Ogba, Magodo, Agege, Unity estates and others. The Commercial areas showed 
an upward trend especially at Iyana Iba bus stop at $66 \mu \mathrm{g} / \mathrm{m}^{3}$ and other locations recording between $9 \mu \mathrm{g} / \mathrm{m}^{3}$ to $40 \mu \mathrm{g} / \mathrm{m}^{3}$ while the industrial land uses recorded between $56 \mu \mathrm{g} / \mathrm{m}^{3}$ to $12 \mu \mathrm{g} / \mathrm{m}^{3}$ at Wapco, Ikeja, Wema and other industrial points. But in 2012 the residential points reduced a little to $36 \mu \mathrm{g} / \mathrm{m}^{3}$ at Adekunle estate and $20 \mu \mathrm{g} / \mathrm{m}^{3}$ at Ogba and Ikeja GRAs with the remaining residential areas accounting for between $7 \mu \mathrm{g} / \mathrm{m}^{3}$ to $18 \mu \mathrm{g} / \mathrm{m}^{3}$. In the commercial locations between $27 \mu \mathrm{g} / \mathrm{m}^{3}$ to $30 \mu \mathrm{g} / \mathrm{m}^{3}$ were recorded at Maryland, Iyana Iba, Iyana Ipaja junctions, Oshodi and Ajegunle bus stops while industrial locations recorded between $36 \mu \mathrm{g} / \mathrm{m}^{3}$ to $15 \mu \mathrm{g} / \mathrm{m}^{3}$ at Matori industrial estate while other industrial areas.

The residential land uses as showed from the other pollutants recorded the least in concentrations levels as consistent in 2013 with a concentration level of between $36 \mu \mathrm{g} / \mathrm{m}^{3}$ to $12 \mu \mathrm{g} / \mathrm{m}^{3}$ with a peak at Adekunle Junctions while other areas declined in levels of pollutants concentrations. These levels increased in the commercial locations recording between $35 \mu \mathrm{g} / \mathrm{m}^{3}$ to $10 \mu \mathrm{g} / \mathrm{m}^{3}$ at Iyana Iba, Iyana Ipaja, CMS, Mushin and other commercial areas and the peak in the industrial points of $76 \mu \mathrm{g} / \mathrm{m}^{3}$ at Wemabod Ikeja and between $40 \mu \mathrm{g} / \mathrm{m}^{3}$ to $15 \mu \mathrm{g} / \mathrm{m}^{3}$ at Ikeja, Agbara, Matori and Sabo industrial areas.

\subsection{Sulfur (IV) Oxide (SO2) and Nitrogen Dioxide Levels}

Sulfur(IV)Oxide recorded in part per million(ppm) in figure 6 was not detected at all in all the residential location sampled in 2010 while between 2011 to 2013. SO $\mathrm{SO}_{2}$ levels in the entire residential points sampled ranged between $00.021 \mathrm{ppm}, 0.032 \mathrm{ppm}$ and $0.07 \mathrm{ppm}$. These levels remained steady in the commercial areas during the period 2010 to 2013 as it ranged between $0.039 \mathrm{ppm}, 0.209 \mathrm{ppm}, 0.115 \mathrm{ppm}$ and $0.11 \mathrm{ppm}$ in Maryland Junction Ikeja, General Hospital Frontage Ikeja, Pencinema Junction Agege, CMS Bus Stop, Lagos Island, Iyana Iba Bus Stop Ojo, Iyana Ipaja Bus Stop, Agege Ojodu Berger Bus Stop Ikeja, Oshodi Bus Stop Oshodi-Isolo, Ajegunle Junction, Apapa and Mushin Bus Stop. The levels were at variance during the period 2010 to 2013 in the industrial points sampled and ranged between $0.188 \mathrm{ppm}$ in 2010,0.035ppm in 2011,0.112ppm in 2012 and in $20130.05 \mathrm{ppm}$ respectively.

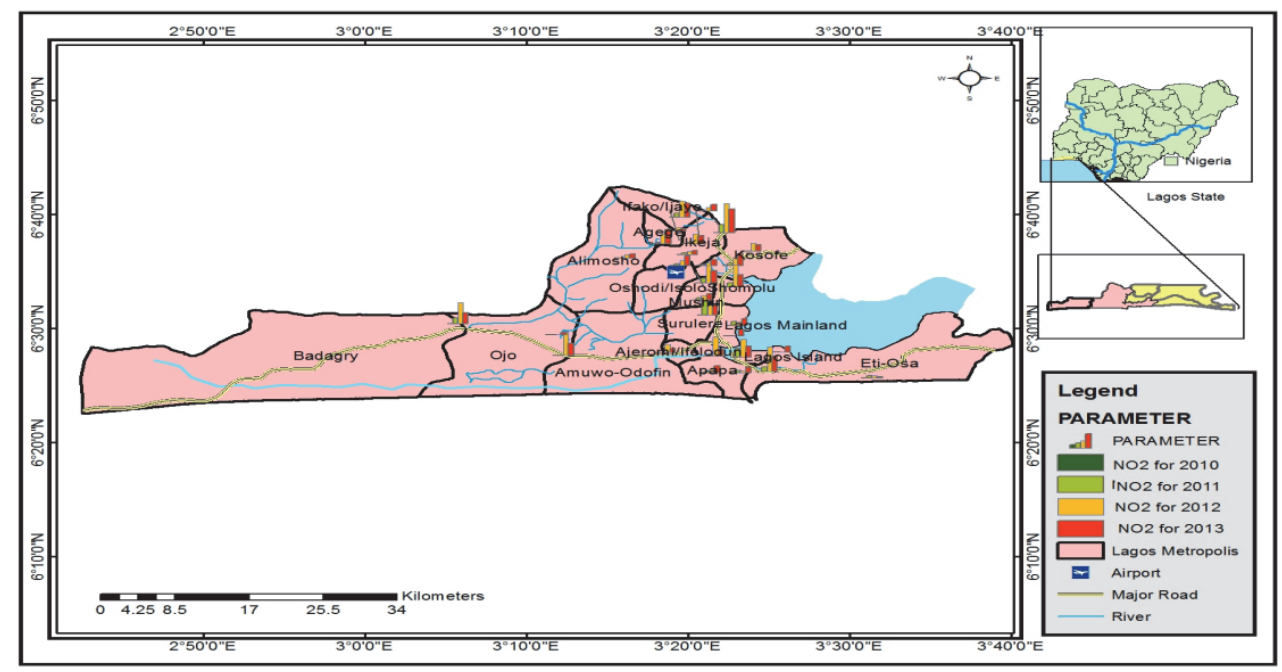

Figure 7. Spatial Variation of Nitrogen (IV) Oxide Over Land Uses Between 2010-2013

Similarly, Nitrogen dioxide in figure 7 above was not detected in the residential sampled points in 2010 and was detected minimally between 2011 to 2013 with mean concentrations of $0.0005 \mathrm{ppm}, 0.039 \mathrm{ppm}$ and $0.056 \mathrm{ppm}$ respectively. The commercial points sampled did not detect $\mathrm{NO}_{2}$ concentration in 2010 and minimally detected concentrations between 2011 to 2013 at mean levels of $0.056 \mathrm{ppm}, 0.225 \mathrm{ppm}$ and 0.1485 respectively. In the industrial locations the same pattern was discovered as $\mathrm{NO}_{2}$ was not detected in 2010 but detected between 2011 to 2013 at a mean range of $0.028 \mathrm{ppm}, 0.056 \mathrm{ppm}$ and $0.081 \mathrm{ppm}$ respectively.

These marked variation in sulpur(iv)oxide, nitrogen(iv)oxide and fine particulate matter over residential, commercial and industrial land uses is consistent with the findings of Superczynski and Sundar (2011) who investigated the impacts of land use land-cover changes on air quality in Alabama USA and discovered higher levels of pollutants over commercial and industrial areas than residential areas, Offor, et al (2016) who reviewed the concentration levels of particulate matter in Nigerian cities revealed high levels of pollutants in commercial than residential areas, Jenq-Hwan, et al (2017) who examine the impacts of particulate matter on tuberculosis cases in Taipei city Taiwan, noted that higher levels of particulate matter was responsible for the intensity of tuberculosis 
cases, Gang, et al (2016) who investigated the impacts of land use on air quality in Wuhan, China stated that land use is the precursor for elevated levels of pollutants and Ipeaiyeda, and Adegboyega (2017) investigation of the concentration levels of air pollutants along traffic corridors of Ibadan city discovered consistent elevated levels of pollutants across commercial areas than industrial and residential areas in Ibadan city.

\section{Statistical Techniques}

Pearson Product Moment Correlation Coefficients was employed as shown in table 1 to 4 to assess the relationship between land uses and air pollutants for nitrogen (iv) oxide, sulfur (iv) oxide, fine particulate matter and carbon monoxide.

Table 7 showed that there is a strong positive relationship between $\mathrm{NO}_{2}$ in industrial in 2012 and in 2013 ( $\mathrm{R}=$ $0.775)$ and also industrial $\mathrm{NO}_{2}$ in 2011, in $2012(\mathrm{R}=0.811)$ and industrial in 2011 and 2013( $\left.\mathrm{R}=0.689\right)$. A negative relationship was discovered between $\mathrm{NO}_{2}$ industrial in 2011 and $\mathrm{NO}_{2}$ residential in $2013(\mathrm{R}=-0.805)$ and also in industrial in 2012 and residential in $2013(\mathrm{R}=-0.677)$.

Table 6 revealed that $\mathrm{SO}_{2}$ levels and land uses had a strong positive relationship in the following periods; between $\mathrm{SO}_{2}$ residential in 2012 and in $2013(\mathrm{R}=0.706), \mathrm{SO}_{2}$ residential in 2012 and $\mathrm{SO}_{2}$ industrial in $2010(\mathrm{R}=0.635)$, residential $\mathrm{SO}_{2}$ in 2013 and commercial $\mathrm{SO}_{2}$ in $2013(\mathrm{R}=0.695)$ and between industrial $\mathrm{SO}_{2}$ in 2012 and $2013(\mathrm{R}=$ 0.694). Negative relationships was also discovered between $\mathrm{SO}_{2}$ commercial in 2010 and in $2013(\mathrm{R}=-0.786)$ and in residential in 2011 and commercial in 2012( $\mathrm{R}=-0.703)$.

A strong positive relationship exists between fine particulate matter levels and residential land use in 2012 and in 2013( $\mathrm{R}=0.887)$ as shown in Table 5 .

In Table 4, there are strong positive relationships between carbon monoxide concentration and industrial land use in 2012 and 2013( $\mathrm{R}=0.822), 2011$ and $2013(\mathrm{R}=0.903), 2011$ and $2012(\mathrm{R}=0.750)$ and in 2010 and $2012(\mathrm{R}=$ $0.640)$. In the commercial areas also strong positive relationships was found in 2010 and $2011(\mathrm{R}=0.763)$, commercial and residential in 2011( $R=0.633)$ and residential in 2012 and $2013(\mathrm{R}=0.680)$. However, a negative relationship was tested between industrial $\mathrm{CO}$ in 2013 and residential $\mathrm{CO}$ in $2011(\mathrm{R}=-0.647)$.

Table 4. Correlation between Carbon (iv) oxide $\left(\mathrm{CO}_{2}\right)$ and Land uses

\begin{tabular}{|c|c|c|c|c|c|c|c|c|c|c|c|c|}
\hline & $\begin{array}{l}\text { carbonmo } \\
\text { noxide in } \\
\text { residential } \\
\text { in } 2010\end{array}$ & $\begin{array}{l}\text { carbonmo } \\
\text { noxide in } \\
\text { residential } \\
\text { in } 2011\end{array}$ & $\begin{array}{l}\text { carbonmo } \\
\text { noxide in } \\
\text { residential } \\
\text { in } 2012\end{array}$ & $\begin{array}{l}\text { carbonmo } \\
\text { noxide in } \\
\text { residential } \\
\text { in } 2013\end{array}$ & $\begin{array}{l}\text { carbonmo } \\
\text { noxide in } \\
\text { commerci } \\
\text { al in } 2010\end{array}$ & $\begin{array}{l}\text { carbonmo } \\
\text { noxide in } \\
\text { commerci } \\
\text { al in } 2011\end{array}$ & $\begin{array}{l}\text { carbonmo } \\
\text { noxide in } \\
\text { commerci } \\
\text { al in } 2012\end{array}$ & $\begin{array}{l}\text { carbonmo } \\
\text { noxide in } \\
\text { commerci } \\
\text { al in } 2013\end{array}$ & $\begin{array}{l}\text { carbonmo } \\
\text { noxide in } \\
\text { industrial } \\
\text { in } 2010\end{array}$ & $\begin{array}{l}\text { carbonmo } \\
\text { noxide in } \\
\text { industrial } \\
\text { in } 2011\end{array}$ & $\begin{array}{l}\text { carbonmo } \\
\text { noxide in } \\
\text { industrial } \\
\text { in } 2012\end{array}$ & $\begin{array}{l}\text { carbonmo } \\
\text { noxide in } \\
\text { industrial } \\
\text { in } 2013\end{array}$ \\
\hline $\begin{array}{l}\text { carbonmo } \\
\text { noxide in } \\
\text { residential } \\
\text { in } 2010\end{array}$ & 1 & & & & & & & & & & & \\
\hline $\begin{array}{l}\text { carbonmo } \\
\text { noxide in } \\
\text { residential } \\
\text { in } 2011\end{array}$ & -.040 & 1 & & & & & & & & & & \\
\hline $\begin{array}{l}\text { carbonmo } \\
\text { noxide in } \\
\text { residential } \\
\text { in } 2012\end{array}$ & .013 & .615 & 1 & & & & & & & & & \\
\hline $\begin{array}{l}\text { carbonmo } \\
\text { noxide in } \\
\text { residential } \\
\text { in } 2013\end{array}$ & -.086 & .566 & $.680\left(^{*}\right)$ & 1 & & & & & & & & \\
\hline $\begin{array}{l}\text { carbondio } \\
\text { xide in } \\
\text { commerc } \\
\text { in } 2010\end{array}$ & .225 & $.633\left(^{*}\right)$ & .389 & .157 & 1 & & & & & & & \\
\hline carbonmo & .156 & .557 & .119 & -.163 & $.763\left({ }^{*}\right)$ & 1 & & & & & & \\
\hline
\end{tabular}




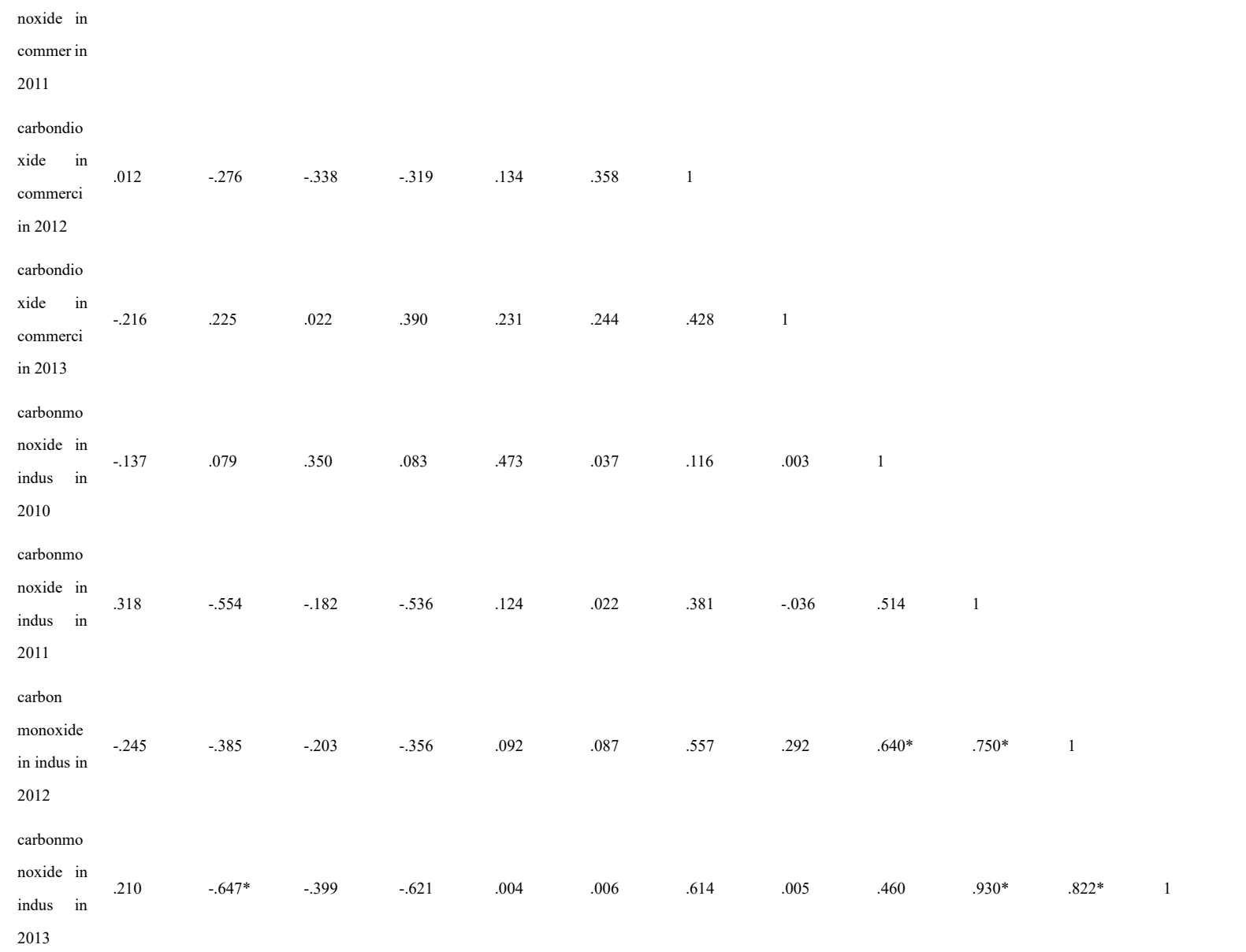

Correlation at 0.05 Significant levels

Field Work, 2014

Table 5. Correlation for Fine Particulate Matter (Pm 2.5) and Land uses

\begin{tabular}{|c|c|c|c|c|c|c|c|c|c|c|c|c|}
\hline & $\begin{array}{l}\text { PM2.5 in } \\
\text { residential } \\
\text { in } 2010\end{array}$ & $\begin{array}{l}\text { PM2.5 in } \\
\text { residential } \\
\text { in } 2011\end{array}$ & $\begin{array}{l}\text { PM2.5 in } \\
\text { residential } \\
\text { in } 2012\end{array}$ & $\begin{array}{l}\text { PM2.5 in } \\
\text { residential } \\
\text { in } 2013\end{array}$ & $\begin{array}{l}\text { PM2.5 in } \\
\text { commercial } \\
\text { in } 2010\end{array}$ & $\begin{array}{l}\text { PM2.5 in } \\
\text { commercial } \\
\text { in } 2011\end{array}$ & $\begin{array}{l}\text { PM2.5 in } \\
\text { commercial } \\
\text { in } 2012\end{array}$ & $\begin{array}{l}\text { PM2.5 in } \\
\text { commercial } \\
\text { in } 2013\end{array}$ & $\begin{array}{l}\text { PM2.5 in } \\
\text { industrial } \\
\text { in } 2010\end{array}$ & $\begin{array}{l}\text { PM2.5 in } \\
\text { industrial } \\
\text { in } 2011\end{array}$ & $\begin{array}{l}\text { PM2.5 in } \\
\text { industrial } \\
\text { in } 2012\end{array}$ & $\begin{array}{l}\text { PM2.5 in } \\
\text { industrial } \\
\text { in } 2013\end{array}$ \\
\hline $\begin{array}{l}\text { PM2.5 in } \\
\text { residential } \\
\text { in } 2010\end{array}$ & 1 & & & & & & & & & & & \\
\hline $\begin{array}{l}\mathrm{PM} 2.5 \text { in } \\
\text { residential } \\
\text { in } 2011\end{array}$ & .035 & 1 & & & & & & & & & & \\
\hline $\begin{array}{l}\text { PM2.5 in } \\
\text { residential } \\
\text { in } 2012\end{array}$ & -.052 & -.150 & 1 & & & & & & & & & \\
\hline $\begin{array}{l}\mathrm{PM} 2.5 \text { in } \\
\text { residential } \\
\text { in } 2013\end{array}$ & -.156 & -.255 & $.887\left({ }^{*}\right)$ & 1 & & & & & & & & \\
\hline $\begin{array}{l}\text { PM2.5 in } \\
\text { commercial } \\
\text { in } 2010\end{array}$ & .035 & -.079 & -.362 & -.097 & 1 & & & & & & & \\
\hline $\begin{array}{l}\mathrm{PM} 2.5 \quad \text { in } \\
\text { commercial }\end{array}$ & .421 & .176 & .071 & .139 & .543 & 1 & & & & & & \\
\hline
\end{tabular}




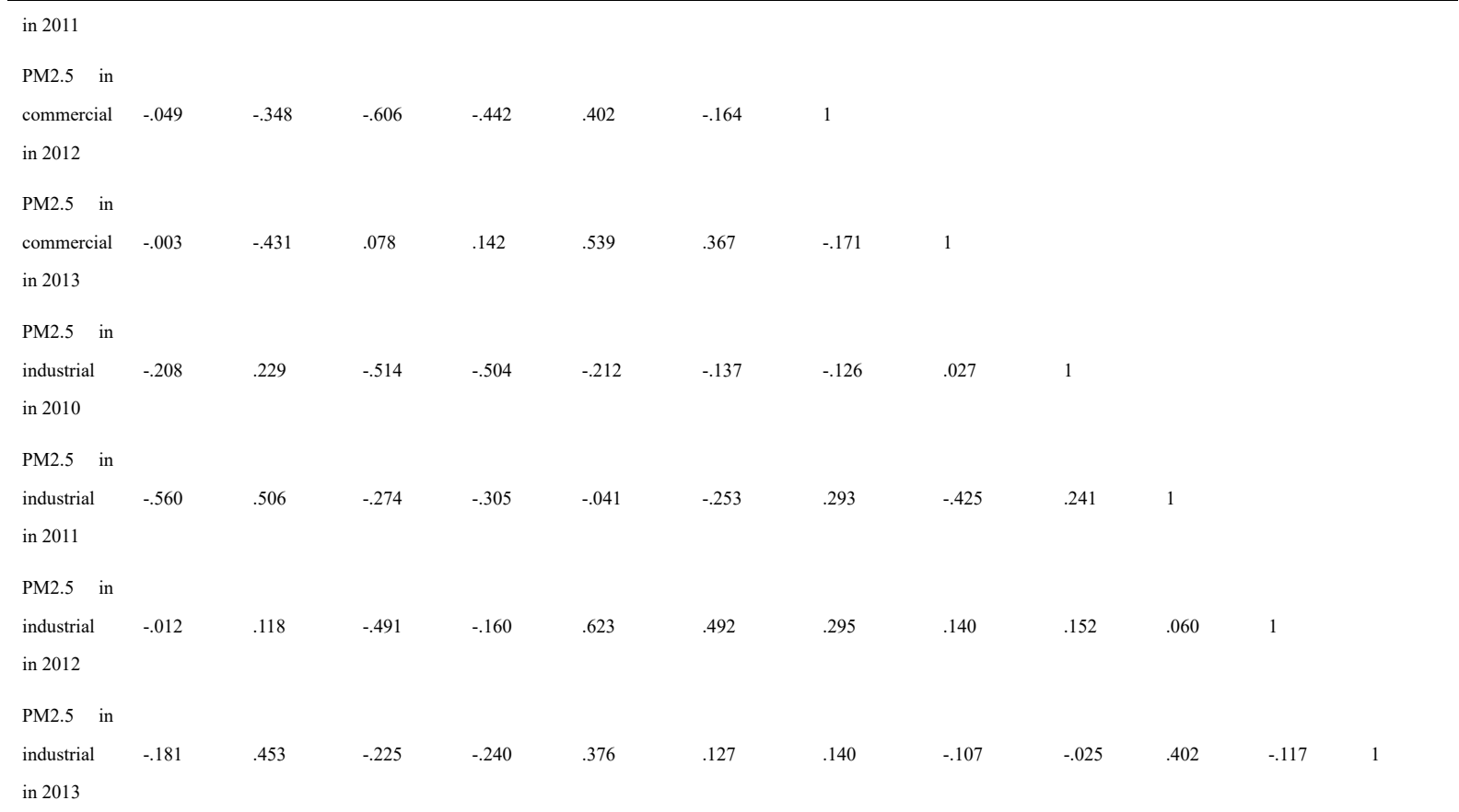

Correlation at 0.05 Significant levels

Field Work, 2014

Table 6. Correlation for Sulfur (iv) dioxide and Land uses

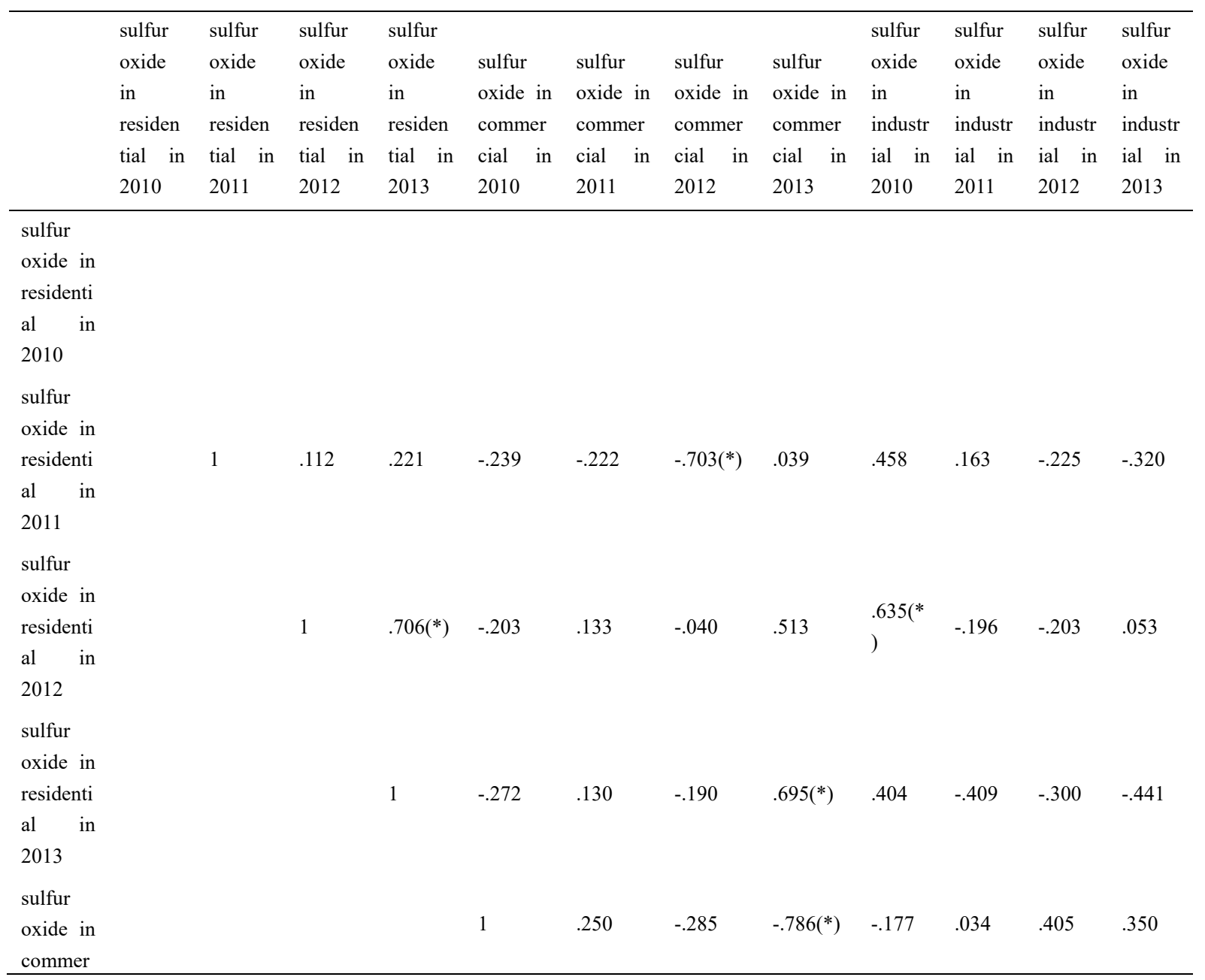




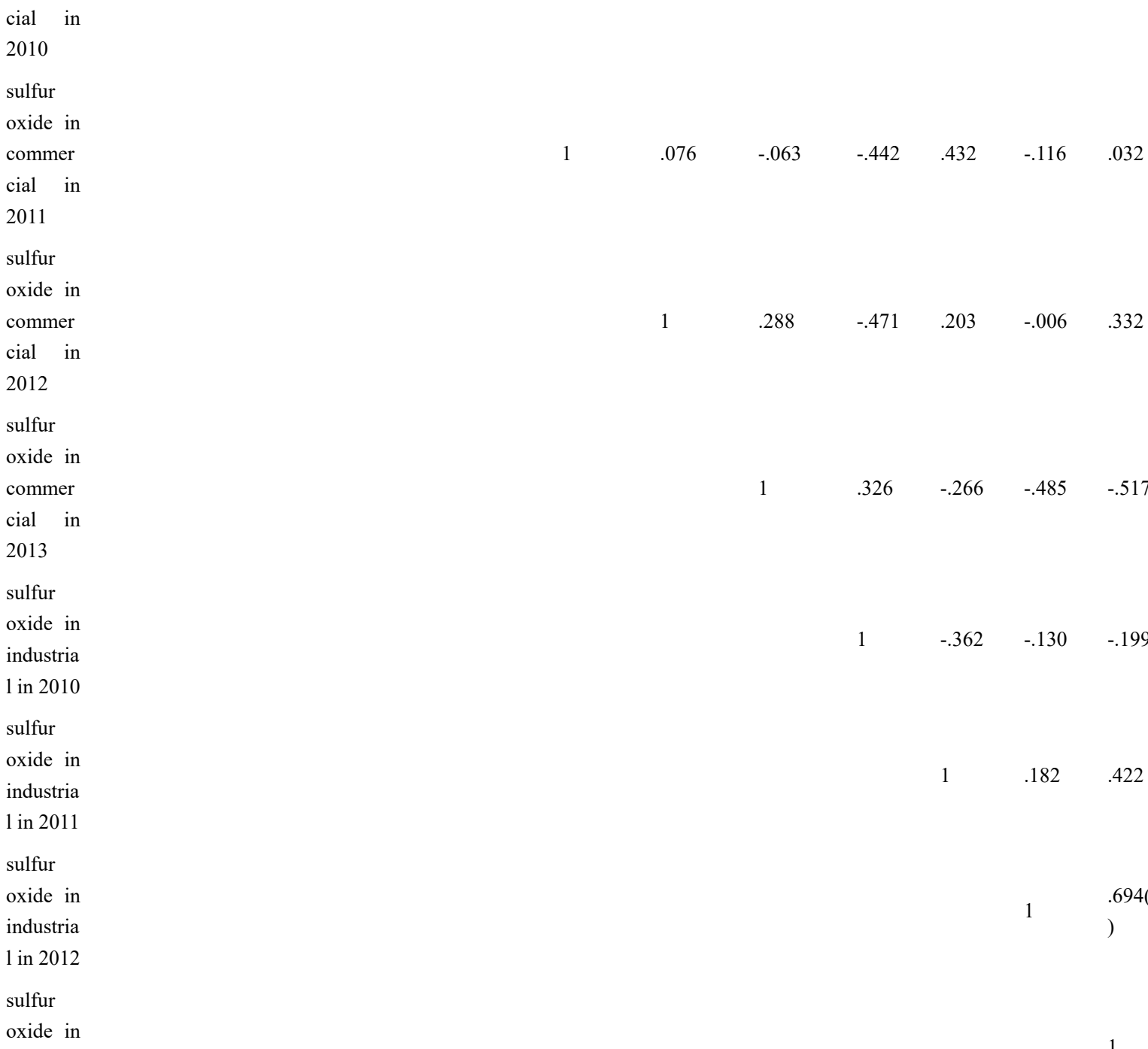




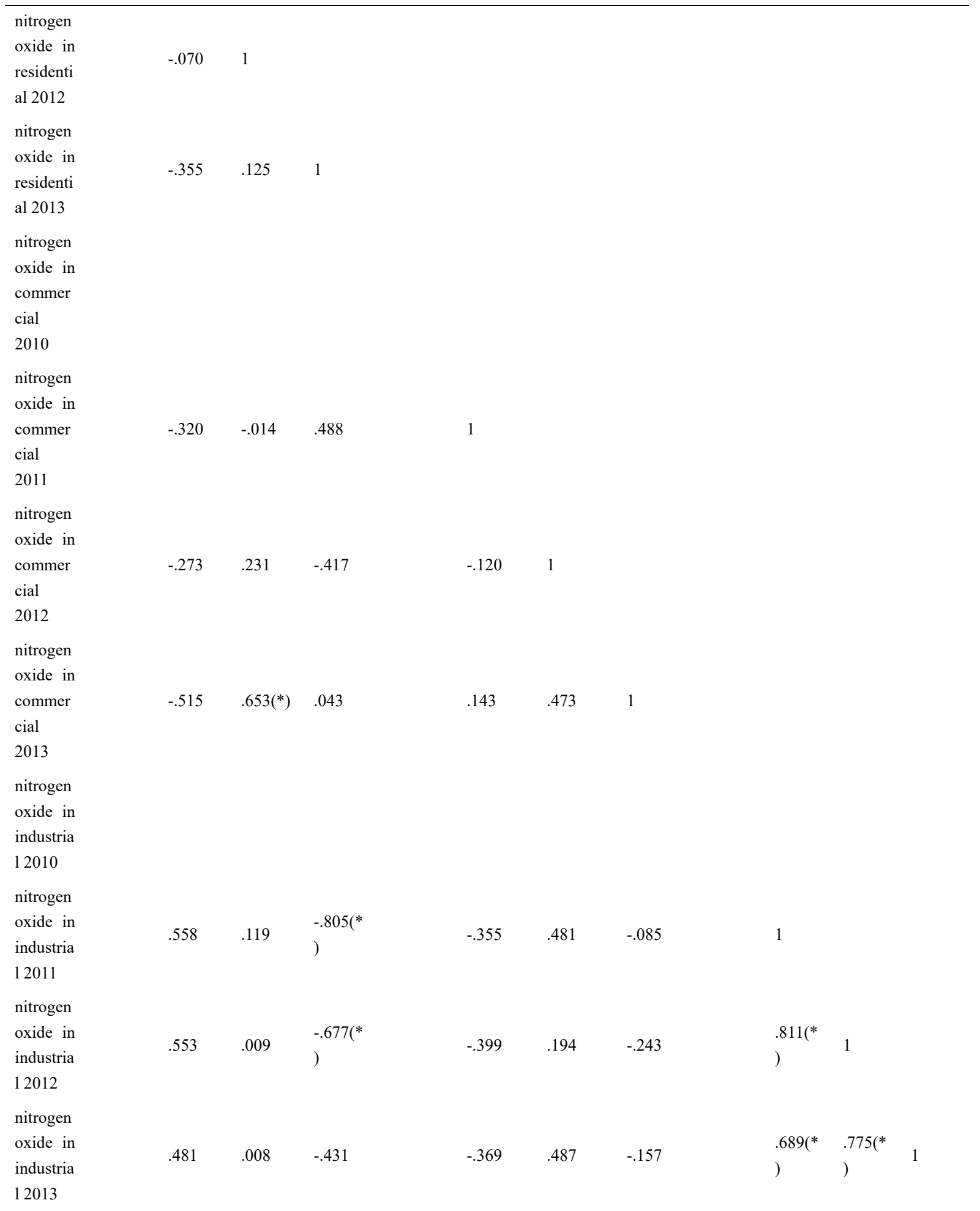

Correlation at 0.05 Significant levels

Field Work, 2014

\section{Conclusion}

Air pollution is majorly caused by human activities which range from combustion in the residential areas to the commercial and industrial areas where valorisation of raw materials are carried out. These actions all contributes to the pollution of the planetary layers which comprises of the turbulent and laminar layers. The turbulent layer therefore transports these pollutants over long distance through wind sequestration where they are deposited as sinks on vegetation cover and inhaled through the nostril of humans and animals. These depositions are washed 
away into the soil through precipitation leading to the increase in the acidity and alkalinity of the soil. In humans and animals, the pollutants inhaled are later manifested as health problems leading to sole throats, asthma and other respiratory ailments. Lagos metropolis is currently recording higher pollution concentration from commercial and industrial areas due to her position as the commercial and industrial nerve center of Nigeria. Lagos state is the most industrialized second to Ogun state of Nigeria. With a current population of $6 \mathrm{~m}$ in the city and a net migration of $1 \mathrm{~m}$ people daily the need for more energy to drive the economy of the city is imperative which on the flip side is the cause of the low air quality according to the concept of Environmental Kuznets Curve in the city.

The findings concluded that carbon monoxide (CO) was the highest in the commercial areas at an average of $7 \mathrm{ppm}$ than the industrial land uses at $4 \mathrm{ppm}$ and residential at $1.5 \mathrm{ppm}$. Fine particulate matter in the residential areas recorded an average of $50 \mu \mathrm{g} / \mathrm{m}^{3}$ than the commercial areas at $60 \mu \mathrm{g} / \mathrm{m}^{3}$ and the industrial areas at $70 \mu \mathrm{g} / \mathrm{m}^{3} . \mathrm{SO}_{2}$ and $\mathrm{NO}_{2}$ weren't detected over the different land uses between 2010 to 2013. Pearson product moment correlation coefficients employed to test for the relationship between land uses and air pollutants for Nitrogen(iv)oxide $\left(\mathrm{NO}_{2}\right)$, Sulfur(iv)oxide $\left(\mathrm{SO}_{2}\right)$, Fine particulate matter $\left(\mathrm{PM}_{2.5}\right)$ and Carbon monoxide $(\mathrm{CO})$ revealed strong positive relationships between $\mathrm{NO}_{2}$ in industrial in 2012 and $2013(\mathrm{R}=0.775)$, industrial $\mathrm{NO}_{2}$ in 2011 and 2012 $(\mathrm{R}=0.811)$ and industrial $\mathrm{NO}_{2}$ in 2011 and $2013(\mathrm{R}=0.689)$. While, negative relationships were discovered between $\mathrm{NO}_{2}$ industrial in 2011 and residential in $2013(\mathrm{R}=-0.805)$ and industrial 2012 and residential in 2013( $\mathrm{R}=-0.677)$. For $\mathrm{SO}_{2}$, a strong positive relationships were revealed for $\mathrm{SO}_{2}$ in residential in 2012 and $2013(\mathrm{R}=0.706)$, residential in 2012 and industrial in $2010(\mathrm{R}=0.635)$, residential $\mathrm{SO}_{2}$ in 2013 and commercial $\mathrm{SO}_{2}$ in $2013(\mathrm{R}=0.695)$ and between industrial $\mathrm{SO}_{2}$ in 2012 and $2013(\mathrm{R}=0.694)$. On the flip side negative relationships were tested between $\mathrm{SO}_{2}$ commercial in 2010 and $2013(\mathrm{R}=-0.786)$ and residential in 2011 and commercial in $2012(\mathrm{R}=-0.703)$. For fine particulate matter, a strong positive relationship in residential in 2012 and in 2013( $\mathrm{R}=0.887)$ and for $\mathrm{CO}$, a strong positive relationship was tested between carbon monoxide concentration and industrial land use in 2012 and $2013(\mathrm{R}=0.822)$, in 2011 and $2013(\mathrm{R}=0.903)$, in 2011 and $2012(\mathrm{R}=0.750)$ and 2010 and $2012(\mathrm{R}=0.640)$. In the commercial areas, strong positive relationships were discovered in 2010 and $2011(\mathrm{R}=0.763)$, commercial and residential in 2011 $(\mathrm{R}=0.633)$ and residential in 2012 and $2013(\mathrm{R}=0.680)$ while a negative relationship was tested between industrial $\mathrm{CO}$ in 2013 and residential $\mathrm{CO}$ in $2011(\mathrm{R}=-0.647)$.

The findings is an indication of the negative effects of land-use on air quality in Lagos metropolis caused by the rapidity in industries, motorize transport and consumption of energy. This portends an upward trend in pollutants concentration which will affect the health of the inhabitants and the environmental receptors.It is hope that a better alternative to energy utilization like the use of bio-friendly sources of energy like solar, bio-char, jetropha etc will be use for energy consumption and the enactments of relevant laws on air pollution to reduce the rates of emissions from commercial and industrial areas. Higher levels of pollutants effects are manifold and there is a need for the reduction of these pollutants levels to protect the health of people and the survival of the ecosystems.

Finally, a seasonal investigation of ambient air pollution levels and the effects of meteorological conditions are imperative in the industrial areas of Lagos metropolis for the assessment of obnoxious levels of pollutants on human and environmental receptors in the city.

\section{References}

Ajayi, D. D. (2007) Recent Trends and Patterns in Nigeria's Industrial Development. Council for the Development of Social Science Research in Africa, Africa Development. XXXII(2), 139-155

Akanni, C. O. (2010) Spatial and seasonal analyses of traffic-related pollutant concentrations in Lagos Metropolis, Nigeria. African Journal of Agricultural Research, 5(11), 1264-1272.

Akunnaya P. O., \& Adedapo O. (2014) Trends in Urbanization: Implication for Planning and Low-Income Housing Delivery in Lagos, Nigeria. Journal of Architecture Research, 4(1A), 15-26.

Alfred, J., \& Hyeladi, A. (2013) Assessment of vehicular emissions and health impacts in Jos, Plateau State. Journal of Research in Environmental Science and Toxicology, 2(4), 80-86. Retrieved from www.interesjournals.org/JREST

Amit, K. G., Tuluri, F., Tchounwou, P. B., Shaw, N., \& Jain, K. G. (2015). Establishing the Association between Quarterly/Seasonal Air Pollution Exposure and Asthma Using Geospatial Approach. Aerosol and Air Quality Research, 15, 1525-1544. https://doi.org/10.4209/aaqr.2014.09.0218

Ana, G. R. (2011). Air Pollution in the Niger Delta Area: Scope, Challenges and Remedies, the Impact of Air Pollution on Health, Economy, Environment and Agricultural Sources. In Tech. Retrieved from www.intechopen.com/books/the-impact-of-airpollution-on-health-economy-environment-and-agricultural- 
sources/air-pollution-in-the-niger-delta-area-scopechallenges-and-remedies

Asubiojo, O. I. (2016). Pollution Sources in the Nigerian Environment and their Health Implications. Ife Journal of Science, 18(4), 1-8, Ile Ife.

Asuoha, A. N., \& Osu, C. I. (2015). Seasonal Variation of Meteorological Factors on Air Parameters and the Impacts of Gas Flaring on Air Quality of Some Cities in Niger delta (Ibeno and its Environs). African Journal of Environmental Science and Technology, 9(3), 218-227. River state Nigeria.

Ayoade, J. O. (2012). Introduction to Building and Urban Climatology, Pp.78 Agbo Areo Publishers Ibadan.

Bicik, et al. (2015) Land Use Changes in the Czech Republic 1845-2010, Chapter 2 Land Use Research Springer International Publishing Switzerland, Springer Geography.

Charfeddine, L., Afnan Yousef A., \& Khloud, A. (2016) Air Pollution in Qatar: Causes and Challenges. College of Business and Economics, Qatar University White Paper, 1(3), 1-7.

Choi, J. H., Xu, Q. S., Park, S. Y., Kim, J. H., Hwang, S. S., Lee, K. H., Lee, H. J., \& Hong, Y. C. (2007). Seasonal variation of effect of air pollution on blood pressure, Journal of Epidemiology Community Health; Vol.61:Pp.314-318. Correspondence to: Professor Y-C Hong, Department of Preventive Medicine, Seoul National University College of Medicine, 28 Yongon-Dong, Chongno-Gu, Seoul 110- 799, South Korea; (doi: 10.1136/jech.2006.049205)

Dotun, O. (2011) How Clean Is the Air Nigerians Breathe? - A Case for National Air Quality Management Framework, Nigeria World, (http://nigeriaworld.com/articles/2011/ feb/012)

Economic Intelligence Unit Issue 1 (2012). Lagos State of Nigeria.

Ediagbonya, T. F., \& Tobin, A. E. (2013), Air Pollution and Respiratory Morbidity in an Urban Area of Nigeria. Greener Journal of Environmental Management and Public Safety, 2(1), 10-15. Retrieved from www.gjournals.org

Ekpenyong, C. E., Ettebong, E. O., Akpan, E. E., Samson, T. K., \& Nyebuk E. D. (2012). Urban City Transportation Mode and Respiratory Health Effect of Air Pollution: A Cross-Sectional Study among Transit and Non-Transit Workers in Uyo City. Nigeria. BMJ (doi: 10.1136/bmjopen-2012-001253)

Gang, X., Limin, J., Suli, Z., Man, Y., Xiaoming, L., Yuyao, H., Boen, Z., \& Ting, D. (2016) Examining the Impacts of Land Use on Air Quality from a Spatio-Temporal Perspective in Wuhan, China. Journal of Atmosphere, 7(62), 2-18.

Gang, Xu, Limin, J., Suli, Z., Man, Y., Xiaoming, Li, Yuyao, H., Boen, Z., \& Ting D., (2016) Examining the Impacts of Land Use on Air Quality from a Spatio-Temporal Perspective in Wuhan, China. Atmosphere, 7 , 62.

Ipeaiyeda, A. R., \& Adegboyega, D. A. (2017). Assessment of Air Pollutant Concentrations Near Major Roads in Residential, Commercial and Industrial Areas in Ibadan City, Nigeria. Journal of Health and Pollution, 7(13), 1565-1580.

Jenq-Hwan, O., Shihn-Sheng, W., Chun-Hung, R. L., Tzu-Ying, W., \& Yen-Hsia W. (2017). Particulate Matter Air Pollution and Tuberculosis: Exploring the Optimal Exposure Assessment, Taipei City Taiwan. Proceedings of ISER 64th International Conference, Nagoya, Japan, 7th -8th July 2017.

Levinson, A. (2000). Environmental Kuznets Curve (entry in forthcoming New Palgrave Dictionary of Economics 2nd edition)

National Bureau of Statistics, World Urbanization Prospects and the Nigerians Population Commission Fact Sheet Report 2017.

Nwachukwu, A. N., Chukwuocha, E. O., \& Igbudu, O. (2012). A survey on the effects of air pollution on diseases of the people of Rivers State, Nigeria. African Journal of Environmental Science and Technology, 6(10), 371379. Retrieved from http://www.academicjournals.org/AJEST https://doi.org/10.5897/ AJEST12.024)

Nwagwu, I., \& Oni, T. (2015). Lagos and Its Potentials for Economic Growth, Heinrich Boell Foundation.

Offor, I. F., Adie, G. U., \& Ana, G. R. (2016). Review of Particulate Matter and Elemental Composition of Aerosols at Selected Locations in Nigeria from 1985-2015. Journal of Health and Pollution, 6(10), 1-18.

Ogwu, F. A., Ajayi, A. P., Aliyu, H. B., \& Nuzhat, A. (2015). An Investigative Approach on the Effect of Air Pollution on Climate Change and Human Health in the Niger Delta Region of Nigeria. International Journal of Scientific Research and Innovative Technology, 2(5), 1-13. 
Oteri, A. U., \& Ayeni, R. A. (2016). The Lagos Megacity, Water Mega Cities and Global Change.

Protecting health from increasing air pollution in Ahmedabad (2017). Supporting Research and Analysis for the Ahmedabad Air Information and Response (AIR) Plan May 2017.Ahmedabad Municipal Corporation, Indian Institute of Tropical Meteorology - SAFAR, Indian Institute of Public Health, Gandhinagar and Natural Resources Defense Council.

Roychowdhury, A., Nasim, U., \& Chandola, P. (2016). Towards Clean Air in Nigerian Cities. Centre for Science and Environment, 41, Tughlakabad Institutional Area, New Delhi.

Soumyananda, D. (2004). Environmental Kuznets Curve Hypothesis: A Survey https://doi.org/10.1016/j.ecolecon.2004.02.011

South West Investment Exhibition and Summit (SWIFT) (2017). Report.Fodion Consultants.

Stern, D. I. (2003) the Environmental Kuznets Curve, International Society for Ecological Economics, Internet Encyclopedia of Ecological Economics, Department of Economics, Rensselaer Polytechnic Institute, Troy, NY 12180, USA.

Superczynski, S. D., \& Sundar A. C. (2011). Exploring Land Use and Land Cover Effects on Air Quality in Central Alabama Using GIS and Remote Sensing. Journal of Environment and Remote Sensing, 3, 2552-2567.

Taiwo, A. M., Arowolo, T. A., Abdullahi, K. L., \& Taiwo, O. T. (2015). Particulate Matter Pollution in Nigeria, A Review, Proceedings of the 14th International Conference on Environmental Science and Technology Rhodes, Greece, 3-5.

Tejvan P. (2017). Environmental Kuznets Curve (economichelp.org).

The Guardian Nigeria News Paper of Saturday 31st October 2015 on the title Air quality in Lagos by Editor on April 2, 2015 4:30 am. Retrieved from www.ngrguardiannews.com

Tiwari, P. (2015). Computational Methods of Air Quality Indices: A Literature Review. IOSR Journal of Environmental Science, Toxicology and Food Technology (IOSR-JESTFT), 1(5), 46-49. India. Retrieved from www.iosrjournals.org

Umoh, V., Peters, E., Erhabor, G., Ekpe, E., \& Ibok, A. (2013). Indoor air pollution and respiratory symptoms among fishermen in the Niger delta of Nigeria. African Journal of Respiratory Medicine, 9(1), 1-5.

Wang, F., Peng, Y., \& Jiang, C. (2017). Influence of Road Patterns on PM2.5 Concentrations and the Available Solutions: The Case of Beijing City, China. Journal of Sustainability, 9(217), 1-17.

Weli, V. E., \& Adegoke, J. O. (2016). the Influence of Meteorological Parameters and Land use on the Seasonal Concentration of Carbon Monoxide (CO) in the Industrial Coastal City of Port Harcourt, Nigeria. Journal of Pollution Eff Cont., 4, 171. https://doi.org/10.4172/2375-4397.1000171

Xianghua, W. (2010). Industrial Pollution, Point Sources of Pollution: Local Effects and its Control. Encyclopedia of Life Support Systems (EOLSS), I. Beijing, China

Xiaolin X., Zhang A., Liang S., Qingwen Qi, Jiang L., \& Yanjun, Y. (2017). The Association between Air Pollution and Population Health Risk for Respiratory Infection: A Case Study of Shenzhen, China. Int. J. Environ. Res. Public Health, 14, 950. (doi: 10.3390/ijerph14090950)

Zagha, O., \& Nwaogazie, I. L. (2015). Roadside Air Pollution Assessment in Port-Harcourt, Nigeria. Standard Scientific Research and Essays, 3(3), 066-074. (ISSN: 2310-7502) Retrieved from http://www.standresjournals.org/journals/SSRE

Zhu, J., Yan, Y., He, C., \& Wang, C (2015). China's Environment Big Issues, Accelerating Effort, Ample Opportunities. Environmental Services Goldman, 6.

\section{Copyrights}

Copyright for this article is retained by the author(s), with first publication rights granted to the journal.

This is an open-access article distributed under the terms and conditions of the Creative Commons Attribution license (http://creativecommons.org/licenses/by/4.0/). 